NBER WORKING PAPER SERIES

\title{
FINANCING ENTREPRENEURSHIP THROUGH THE TAX CODE: ANGEL INVESTOR TAX CREDITS
}

\author{
Sabrina T. Howell \\ Filippo Mezzanotti \\ Working Paper 26486 \\ http://www.nber.org/papers/w26486 \\ NATIONAL BUREAU OF ECONOMIC RESEARCH \\ 1050 Massachusetts Avenue \\ Cambridge, MA 02138 \\ November 2019
}

Howell's research on this project was funded by the Kauffman Foundation and the Kenan Institute Frontiers of Entrepreneurship grant program. We are grateful to Abhishek Bhardwaj, Nick McMonigle, Danye Wang, Grant Goehring, and Jun Wong for excellent research assistance. We thank Will Gornall for data assistance. For helpful comments, we thank Tania Babina, Greg Brown, Ryan Decker, Will Gornall, Arpit Gupta, Simone Lenzu, Arnobio Morelix, Holger Mueller, Andrea Passalacqua, David Robinson, and participants at the NYU Stern Corporate Governance seminar and the Kenan Institute Frontiers of Entrepreneurship Conference. Filippo Mezzanotti thanks Kellogg School of Management for financial support. The views expressed herein are those of the authors and do not necessarily reflect the views of the National Bureau of Economic Research.

NBER working papers are circulated for discussion and comment purposes. They have not been peer-reviewed or been subject to the review by the NBER Board of Directors that accompanies official NBER publications.

(C) 2019 by Sabrina T. Howell and Filippo Mezzanotti. All rights reserved. Short sections of text, not to exceed two paragraphs, may be quoted without explicit permission provided that full credit, including $\odot$ notice, is given to the source. 
Financing Entrepreneurship through the Tax Code: Angel Investor Tax Credits

Sabrina T. Howell and Filippo Mezzanotti

NBER Working Paper No. 26486

November 2019

JEL No. G0,G18,G24,G38,O3

\begin{abstract}
$\underline{\text { ABSTRACT }}$
A central issue in public finance is the tradeoff between maintaining tax revenues and using the tax code to incentivize particular economic activities. One important dimension of this tradeoff is whether incentive policies are used in practice as policymakers intend. This paper examines one particular tax program that many U.S. states use to stimulate entrepreneurship. Specifically, angel tax credits subsidize wealthy individuals' investments in startups. This paper finds that these programs have no measurable effect on local entrepreneurial activity or beneficiary company outcomes, despite increasing some measures of angel activity. This appears to reflect the programs failing to screen out financially unconstrained firms and often being used for tax arbitrage. Over 90 percent of beneficiary companies fall into at least one of three categories: a corporate insider received a tax credit; the company previously raised external equity; or the company is not in a high-growth sector. Notably, at least 33 percent of beneficiary companies include an investor receiving a tax credit who is an executive at the company.
\end{abstract}

Sabrina T. Howell

NYU Stern School of Business

KMC 9-93

44 West 4th Street

New York, NY 10012

and NBER

showell@stern.nyu.edu

Filippo Mezzanotti

Kellogg School of Management

4389 Global Hub

2211 Campus Drive

Evanston, IL 60201

filippo.mezzanotti@kellogg.northwestern.edu 


\section{Introduction}

Many local governments are eager to encourage high-growth entrepreneurship as a means to create high-skill jobs and foster economic growth. Subsidies could be effective if financial frictions leave promising early stage startups financially constrained, which may be more often the case outside of major hub cities (Kerr \& Nanda 2011). ${ }^{1}$ One readily available policy tool for a local government is the tax code, which can be deployed to subsidize angel investment in local ventures. Angel investors are high net worth individuals who provide private capital to startups - they are often a startup's first source of outside capital. ${ }^{2}$ Since the 1990s, 30 U.S. states have implemented angel investor tax credits, which are applied via deductions from income taxes owed (not from taxable income).

Subsidizing investors through the tax code has several attractive features relative to alternatives such as direct grants to firms. First, there is no need for government to "pick winners," which might lead to regulatory capture (Lerner 2009). Tax credits retain market incentives, leaving expert investors with some skin in the game. Second, the administrative burden of tax subsidies is relatively low. Keuschnigg \& Nielsen (2002) theorize that by lowering the cost of starting a new business, investment subsidies should increase entrepreneurship and success conditional on entry. Finally, as a targeted subsidy, angel investor tax credits avoid the blunter instrument of lowering capital gains taxes, which applies to a much broader set of investments (Poterba 1989).

Existing literature on related programs provides additional reasons to think that angel investor tax credits will be successful. There is a great deal of evidence, summarized in Becker (2015), that R\&D tax credits have large positive effects on innovation among both large and small firms. ${ }^{3}$ Lower corporate and income taxes spur new business formation and superstar inventor mobility, respectively. ${ }^{4}$ Lach (2002), Bronzini \& Iachini (2014) and Howell (2017)

\footnotetext{
${ }^{1}$ See also Chen, Gompers, Kovner \& Lerner (2010) and Krishnan, Nandy \& Puri (2014)

${ }^{2}$ See The American Angel, a report from the Angel Capital Association, for details on angel investing. https://www.angelcapitalassociation.org/data/Documents/TAAReport11-30-17.pdf?rev=DB68

${ }^{3}$ Specific papers include Hall (1993), McCutchen (1993), Mamuneas \& Nadiri (1996), Hall \& Van Reenen (2000), Bloom, Griffith \& Van Reenen (2002), Billings et al. (2001), Klassen et al. (2004), Wilson (2009), Clausen (2009), Agrawal, Rosell \& Simcoe (2014), Dechezleprêtre et al. (2016), and Balsmeier, Kurakina \& Fleming (2018).

${ }^{4}$ On the former, see Mukherjee et al. (2017), Serrato \& Zidar (2018), and Curtis \& Decker (2018) in the U.S., and Da Rin et al. (2011) in Europe. Relatedly, Zwick \& Mahon (2017) show that small firms
} 
demonstrate positive effects of grant programs for high-tech startups. Finally, accelerator participation and winning new venture competitions - both of which often benefit from public funds - are also useful for startups (McKenzie 2017, Gonzalez-Uribe \& Leatherbee 2017, Howell Forthcoming). The above policies are diverse, yet they have key features that distinguish them from state angel investor tax credits: Rather than targeting financial intermediaries, they either target firms that are likely to be constrained (e.g. high-tech startups) or target specific economic activities (e.g. R\&D investment).

Despite significant take-up and widespread use, we find that state angel investor tax credit programs have no measurable effect on local economic growth. However, the programs do lead to more angel deals and investors. To interpret these facts, we begin by recognizing that there are challenges to implementing angel tax credits. First, a tax credit will only be effective if the company whose investor received it (henceforth "beneficiary company") would not otherwise receive as much financing. ${ }^{5}$ If the company would obtain the financing regardless and would not change its investment behavior, the policy is simply a transfer from taxpayers to investors or other company stakeholders. In such a case, the subsidy crowds out alternative funding sources. Second, the tax credit must target investors in companies with the potential to grow or innovate, especially in order to generate positive spillovers for the local economy. In sum, to be useful, angel tax credit programs must reach companies presenting good investment opportunities that nonetheless face financing frictions. ${ }^{6}$ We document that beneficiary firms often do not appear particularly constrained ex-ante and that tax arbitrage considerations appear to be important in explaining take-up. In line with this interpretation, we document that the increase in state-level AngelList activity is driven

are especially sensitive to temporarily lower investment tax rates. On the latter, see Akcigit, Baslandze \& Stantcheva (2016) and Moretti \& Wilson (2017).

${ }^{5}$ The main motivation for subsidizing angel investment is that financing frictions inhibit optimal investment (Jensen \& Meckling 1976, Stiglitz \& Weiss 1981, Myers \& Majluf 1984). Information asymmetry and agency conflicts between managers and investors reduce the investor's willingness to provide capital despite the company having deserving investment opportunities. Information asymmetry is especially severe among startups (Gompers \& Lerner 1997, Gompers \& Sahlman 2001). Longstanding research shows these financing frictions can translate into reduced real expenditure on investment by the company (Hoshi, Kashyap \& Scharfstein 1991, Hubbard 1998). This literature suggests that subsidies should target those young, entrepreneurial firms facing the most severe information asymmetries.

${ }^{6}$ Tax credits could also be effective if they target firms that are unconstrained and induce them to invest more in areas with large spillovers. However, this requires that firms increase real investment, not simply substitute among liabilities. 
by investors who are less likely to be professional.

We begin the paper by providing comprehensive and systematic information about all 30 state programs, based on examination of each state's tax codes (Table 1 and Appendix Table A.1). The programs are quite generous, as the share of qualified investment that can be deducted from the investor's income taxes, or reimbursed as a cash grant to out-of-state investors, is 33 percent on average and 28 percent at the median. Suppose an angel invested $\$ 100,000$ with the expectation of a "2x multiple," or 200 percent cash-on-cash return (a standard industry return metric). The median tax credit transforms this into a 2.8x multiple. There is wide variation in the amount of money states allocate to the programs, with the smallest program at $\$ 0.75$ million and the largest at $\$ 50$ million. Across all program-years with available data, take-up totals $\$ 8.13$ billion (see Figure 1). This is 88 percent of allocated funding. While these numbers are a small share of total tax revenue, they are large relative to state funding for entrepreneurship, both public and private, as well as to total state angel investment (see Section 2.1).

Our first analysis asks whether the angel tax credit programs are associated with growth in entrepreneurial activity at the state level. Using a difference-in-differences model that exploits the staggered introduction of these programs across states post-2001, we find no impact on the real economy. This is true using employment at young firms overall or in relevant sectors, and using the number of small firms in relevant sectors. For example, the estimated effect of a tax credit on employment at firms zero to five years old is 0.5 percent, with a 95 percent confidence interval upper bound of three percent. Similarly, the coefficient for the number of high-tech firms with less than 20 employees is -0.1 percent, with an upper bound of one percent. These null effects persist across a range of reasonable specifications.

While there is no exact parallel, the real outcomes of alternative programs can serve as useful benchmarks. Balsmeier, Kurakina \& Fleming (2018) find that an California R\&D tax credit increased measures of patents, citations, and the stock market value of patents by between five and 12 percent, and Dechezleprêtre et al. (2016) find that an R\&D tax credit for small firms in the UK increased patenting by 60 percent. In both cases, the R\&D credit value relative to payable taxes is smaller than the average angel credit in our data. Howell \& Brown (2019) find that small business grants that are about five times the average tax 
credit amount increase employment by 27 percent.

We also assess the tax credit programs' relationship to angel investment in the state. Using data from AngelList, where individuals self-identify as angel investors, we find that the programs are associated with more deals and more unique investors. We find positive but smaller and insignificant effects on funding amounts from the commercial datasets, where an aggregator determines what "counts" as angel investment. Both the investment and employment results are persistent across a wide range of reasonable specifications.

One way to explain the results thus far is that the programs have a positive effect, but it is too small to detect in state-level analysis. To assess this hypothesis, we use detailed data on applicant companies from 10 states between 2005 and 2018 to compare beneficiary companies to companies that were certified to receive a tax credit but for which no tax credit was ever issued ("failed applicants"). For an investor to receive a tax credit, the company must be certified by the state as eligible (e.g., must have the majority of its employees in the state). Failed applicants are a useful comparison group to the beneficiary companies because they are in the same state and indicated interest in the tax credit. However, they are likely to be lower quality, leading us to expect any bias to be positive. ${ }^{7}$ Consistent with positive bias, beneficiary companies are on average more successful subsequently than their rejected counterparts. Yet this relationship disappears after controlling for previous financing. ${ }^{8}$ In our preferred models, we find fairly precise zero effects of getting a tax credit on financing, employment, and exit. For example, the effect on having at least 25 employees in the second year after the tax credit year is -0.021 percentage points in our preferred specification, with a 95 percent confidence interval ranging from -0.5 to 0.5 percentage points, relative to a mean of about three percent. As a robustness test, we find similar results using a matching estimator in which control companies are those that received similar amounts of previous financing but are in a different state in the same Census division that never had a tax

\footnotetext{
${ }^{7} \mathrm{~A}$ company that is certified would fail to receive an actual tax credit because: (a) no investment deal occurred, in which case the company may have sought but failed to raise angel investment or raised money from a source that did not claim the state tax credit; or (b) the company applied after the state ran out of funding. In either case, there is no reason to think that a failed applicant would be an intrinsically better company, if anything it is likely to be worse. Indeed, failed applicants raised less previous financing and they had lower pre-application employment.

${ }^{8}$ These results help explain the aggregate results of increased angel investment but limited real effects of the policy.
} 
credit program. Thus, the small size of the programs is not the main reason for the limited state-level effects.

An alternative explanation for the null effects on real activity is that the tax credit programs do not successfully target companies with investment opportunities that will respond to the subsidy. Within this program design explanation, there are two mechanisms. First, perhaps the program did motivate new seed investment, but there was no pass through to investment on the part of the beneficiary company. This might happen if, for example, beneficiary companies were relatively unconstrained ex-ante and the angel investment substitutes for other sources of financing (e.g. bank loans). The second mechanism is that the program is used for tax arbitrage. For example, it may have incentivized existing investors to label themselves "angels" in order to make use of the credit. In both cases, real company investment is unchanged after the credit, but we may observe some increase in state-level angel activity.

To explore whether the data are consistent with these channels, we examine company and investor characteristics in 12 states. We document three facts. First, beneficiary companies tend to be well-financed ex-ante: 37 percent of beneficiary companies previously received equity financing, with large dollar amounts relative to the average angel deal. This contrasts with a common perception that angel investor tax credits target a company's initial external investment and suggests that many beneficiary companies could have raised similar amounts of funding in the absence of the program.

Second, beneficiary companies do not appear to be the type that typically face financing frictions yet have high-growth potential. For example, they are much less likely to be in the IT/web/computer sector than VC-backed startups in general. This sector is important, as it is strongly associated with innovative, high-tech, high-growth firms. ${ }^{9}$ This makes it less likely that the additional investment is "angel" in the sense of funding potentially highgrowth startups. Indeed, we show that the state-level increase in angel activity is primarily explained by one-off investors rather than professional angels with a track record of exits and repeated transactions.

\footnotetext{
${ }^{9}$ Lower spillovers in more traditional sectors could also help explain the absence of an aggregate effect (Griliches 1992, Acs et al. 1994).
} 
Third, we show that investors benefiting from the tax credit are often insiders of the beneficiary company. For five states, we observe the identities of investors who received a tax credit linked to the beneficiary company. We find that 33 percent of these companies have at least one investor who is also a company executive. This rate is likely an underestimate, as it is not straightforward to affirmatively identify insiders. Insider investors by definition do not face information asymmetry, which may help explain why subsidizing them would have a limited impact. Furthermore, insiders are more likely to be in a position to enjoy tax credits without altering investment policy. This evidence is consistent with the tax arbitrage channel.

These outcomes appear to be the result of program design. Angel investor tax credit programs appear not to target companies that would greatly benefit from the subsidy. Instead, firms receiving the tax credit are often not especially constrained, and investors are often company insiders. In a similar vein, Bell et al. (2018) conclude that policies to induce innovation that focus on financial returns, such as cutting top income taxes, are unlikely to be successful. The reasons are parallels to what we find here among angel investors: Such policies target individuals who are already at high likelihood of innovating, and whose effort will be relatively unresponsive to marginal changes in incentives.

However, our results should be interpreted with caution. A null effect conclusion, particularly in a small sample, prevents us from definitively establishing whether or not angel investor tax credit programs are useful. It is possible that with hundreds or thousands of policy changes, we would be able to identify a positive effect. In the analysis, we emphasize the magnitude we can rule out based on the upper bound of 95 percent confidence intervals. These bounds suggest that - perhaps surprisingly - there are no economically meaningful positive effects. We believe that it is important for economists to report null results concerning widely used policies, if only to indicate that further research is needed to affirmatively establish whether these policies are or are not a useful application of taxpayer dollars.

Our paper contributes to work on tax arbitrage and avoidance (e.g. McDonald 2001, Graham 2003, Jacob \& Michaely 2017, Landoni 2018). A second related literature examines how taxes affect VC and has come to disparate conclusions. While Cullen \& Gordon (2007) 
and Bock \& Watzinger (2017) find that higher capital gains taxes reduce investment, Jeng \& Wells (2000) find no effect and Da Rin et al. (2006) find economically small effects. Poterba (1989) points out that most investors in VC funds, such as endowments and pension funds, are in any event tax exempt.

Our paper joins a growing new literature focusing on angel investment, which includes Kerr, Lerner \& Schoar (2011), Bernstein, Korteweg \& Laws (2017), Ewens \& Townsend (2018), Lerner, Schoar, Sokolinski \& Wilson (2018), and Lindsey \& Stein (2019). ${ }^{10}$ In addition to analyzing angel tax credits, our paper sheds light on the characteristics of over 5,600 individuals who receive angel tax credits, including gender and occupation. ${ }^{11}$ Understanding the angel investor ecosystem is important, as angel investors fund far more new ventures than venture capital firms. For example, in 2018, angels invested $\$ 23.1$ billion in 66,110 U.S. startups, while VCs invested in just 8,948 U.S. firms. ${ }^{12}$

Our results are also consistent Gonzalez-Uribe \& Paravisini (2019), who study of a UK tax subsidy for equity investments in small firms. Despite finding that investments are very elastic to changes in the cost of external equity among firms that issue equity, they also document extremely low take-up, with only one percent of eligible firms taking advantage of the subsidy. The apparent difference with our finding of high take-up but relatively low impact is easily explained once we compare the eligibility rules. Unlike many U.S. state tax credit programs, the UK programs exclude insiders from claiming credits. In both studies, the cost of adding new external investors appears to be a significant constraint on growth. This comparison highlights our view that specific design choices explain the unexpectedly limited effects we find. Our analysis suggests that altering eligibility rules might enable state

\footnotetext{
${ }^{10}$ In a contemporaneous paper, Denes et al. (2019) also study angel investor tax credits, providing a complementary but consistent view on these programs. Our paper is different along a number of dimensions. In terms of data, we observe angel investor identities and failed applicant companies, both of which permit unique analyses that we see as crucial to identifying the key mechanism. Relative to our work, Denes et al. (2019) exploits SEC Form D filings as an additional data set. We do not use these data because as far as we are aware they do not permit a distinction between angel investors and other types of investors who use Form D, such as venture capital and hedge funds. The only disclosure requirement in Form D about investors is "number of accredited investors participating in the offering."

${ }^{11}$ The majority of the data on beneficiary companies and their investors have not previously been public and were hand-collected, but we can make complete, identified data available for future use. Complete data with firm and investor identities will be available on the authors' websites.

${ }^{12}$ Statistics from the UNH Center for Venture Research Angel Market Report 2018 and Pitchbook (see https://paulcollege.unh.edu/sites/default/files/resource/files/2018-analysis-report.pdf and https://pitchbook.com/news/articles/18-charts-to-illustrate-us-vc-in-2018).
} 
angel investor tax credit programs to generate outcomes more in line with their stated goals of creating skilled jobs through high-growth entrepreneurship.

Research in entrepreneurial finance and the broader financial sector has demonstrated the importance of frictions, especially information asymmetry (Drucker \& Puri 2008, Duchin et al. 2010, Acharya \& Subramanian 2009, Bottero, Lenzu \& Mezzanotti 2015, Bernstein, Giroud \& Townsend 2016, Hombert \& Matray 2016, Howell Forthcoming). These frictions appear to be unevenly distributed, with some areas benefiting from innovation clusters and others suffering from an absence of new firms (Baumol 1990, Foster, Haltiwanger \& Syverson 2008, Gennaioli et al. 2012, Haltiwanger et al. 2013, Decker et al. 2014). Public policies to promote entrepreneurial activity have the potential for large social welfare gains and come with opportunity costs, so designing them well is important.

\section{Angel Tax Credit Programs}

This section describes our data. First, we use comprehensive characteristics of each state angel investor tax credit program to explain how they operate (Section 2.1). We then discuss characteristics of the angel investors in our data, an important contribution of this study (Section 2.2). Third, we describe the firm-level data we use that will permit us to compare tax credit beneficiary companies with rejected applicants (Section 2.3). Last, we summarize the state-level outcome data we use in our aggregate analysis (Section 2.4).

\subsection{State Angel Tax Credit Programs}

Since 1998, 30 states have deployed angel investor tax credit programs to encourage local high-growth entrepreneurship. The rise of Silicon Valley and the Dotcom boom appear to be important motivating factors, and to our knowledge there were no similar programs in earlier years. The explicit motivation is almost always to increase local economic activity, in particular through an increase in firms employing high-skill, high salary workers. For instance, a typical version is as follows:

"Wisconsin established the Qualified New Business Venture (QNBV) Program in 
2005 to drive investment into early-stage companies with the promise of creating next-generation economic opportunity in Wisconsin...the QNBV Program helps companies create high-paying, high-skill jobs throughout Wisconsin."13

As nearly all programs cite job creation and additional investment as the central goals, the analysis in subsequent sections focuses on employment and financing outcomes.

A contribution of this paper is to provide - to our knowledge - the first systematic and comprehensive documentation of U.S. state angel tax credits, based on examination of the original legislation. Table 1 contains four key variables: The year that the program went into effect, the expiration year, the share of an investment the investor may claim as a deduction from his tax liability (note these are not deductions from taxable income), and the total allocated funding. The investment share varies dramatically, from 10 percent in New Jersey to 100 percent in Hawaii. Some programs are larger than others; for example, Wisconsin permits 50 percent of the investment to be deducted and allocates $\$ 30$ million to the program, while New Mexico permits 25 percent to be deducted and allocates just $\$ 2$ million. There appears to be some competition across states; for example, Iowa increased its investment deduction from 20 to 25 percent for most investors in part to achieve parity with nearby Minnesota and Wisconsin. ${ }^{14}$ Supporting this motivation, Wilson (2009) shows that while state $R \& D$ tax credits do increase local $R \& D$, the effect largely reflects reallocation from other states.

The average individual investment amount benefiting from a tax credit is $\$ 376,000$ (shown in Table 3, based on hand-collected data described below). This is similar to the average angel deal size in the U.S., but much larger than survey data on the average individual angel investment. ${ }^{15}$ Take-up is high, at 88 percent of allocated funding by the state legislature. Summed across all program-years with available data (there are no take-up data for New York or Oklahoma), take-up totals $\$ 8.13$ billion (see Figure 1).

While the programs are typically small relative to overall state budgets, they are

\footnotetext{
${ }^{13}$ Wisconsin Economic Development Corporation 2013 Qualified New Business Venture Program Report.

${ }^{14}$ Based on an interview with a senior program official.

${ }^{15}$ The average angel deal size in recent years is about $\$ 390,000$, according to the UNH Center for Venture Research Angel Market Report 2017. available at https://paulcollege.unh.edu/sites/default/files/resource/files/2017-analysis-report.pdf. Huang et al. (2017) find in survey data that the average angel check is around $\$ 35,000$.
} 
significant portions of the funding allocated to supporting entrepreneurship or small businesses. For example, funding in Ohio, Minnesota, and Wisconsin are respectively 19, 58, and 86 percent of annual state funding for high-tech jobs or small businesses, most of which takes the form of grants. ${ }^{16}$ The state funding amounts are also in many cases large relative to the total annual angel investment in the state, averaged across years where the program is in force (Appendix Table A.1 column 6). For example, dedicated funding is 47 percent of total angel investment in North Carolina and 163 percent in Maine. Most U.S. angel investment takes place outside of states with angel tax credit programs, largely because the major entrepreneurial finance hubs of California and Massachusetts have never had such a program. To illustrate, in 2016 angel investment in tax credit states totaled $\$ 1.97$ billion, with a state average of $\$ 70$ million, compared to a total of $\$ 4.89$ billion and average of $\$ 223$ million in non-tax credit states. This difference appears to have been growing over time. For example, in 2013 states with tax credits averaged $\$ 65$ million in angel investment, compared to $\$ 158$ million in non-tax credit states. $^{17}$

Complete rules and eligibility requirements are listed in subsequent columns of Appendix Table A.1. Where a cell is blank, it means that the state's rules do not explicitly address the criterion. Most states allow angel groups or VCs to benefit as well as individuals. Further, many states use a refundable credit, such that investors may receive a cash grant in lieu of a tax liability deduction if they are out of state or otherwise do not qualify. Most programs have a first-come-first-serve policy in the event funding runs out. In many states the tax credit can be transferred, sold, or carried forward. All but two programs have a maximum company size, defined in terms of revenue, assets, employees or some combination. Fourteen have a maximum firm age for eligibility. Importantly, these programs should not directly relax investor financing constraints, because investors do not receive the credit until after they have completed the investment. ${ }^{18}$ This is different than programs such as direct grants

\footnotetext{
${ }^{16}$ The other programs considered for Ohio are the Pre-Seed/Seed Plus Fund Capitalization Program, The Technology Validation and Start-up Fund, The Ohio Third Frontier initiative and the JobsOhio Research and Development Center Grant Program. The other programs considered for Wisconsin are the Seed Accelerator Program, SBIR/STTR Matching Grant Program, Entrepreneurial Micro-Grant, Capital Catalyst, Entrepreneurship Support Program. The other programs considered for Minnesota are the Innovation Voucher Program and the Minnesota Job Creation Fund.

${ }^{17}$ Statistics based on angel and seed financing compiled from CB Insights and Crunchbase.

${ }^{18} \mathrm{In}$ principle, investors could borrow against the future tax credit. However, this is very unlikely because
} 
that provide companies with money upfront.

Programs consistently require the business to be tied to the local economy. For instance, Illinois requires that at least 51 percent of a company's employees be located in-state and the "principal place of business" to be in Illinois. About two thirds of states have some industry or "innovation" condition, but these are often broad and subjective, potentially including nearly any business that is willing to be creative in its application for certification of eligibility (see Appendix Table A.1 columns 16 and 19). For example, Illinois demands that a beneficiary company have "the potential for increasing jobs, increasing capital investment in Illinois, or both" and be "principally engaged in innovation." In some cases, there is an explicit industry target, usually in manufacturing and/or high-tech sectors. Some features may be surprising; for example, 22 programs explicitly permit the investor to be employed by the company, while only six programs forbid this. We will return to this in Section 4.2.

\subsection{Angel investor characteristics}

For seven states, we collected complete information about angel investor identities (though the start year of data varies across states). They are described in Table 3. In total, there are 5,637 unique individual investors (this excludes group investors, such as VC firms). Note that Minnesota comprises 39 percent of the data. Subsequent statistics in the table have sample sizes that reflect the number of investors for which the variable could be identified on LinkedIn.

We find that 79 percent of subsidized angel investors are located in the same state as the tax credit program; this varies from 23 percent in New Jersey to 91 percent in Illinois. This may reflect the well-known fact that information asymmetry between startups and their investors is more severe when investors are geographically far away (Chen et al. 2010, Bernstein, Giroud \& Townsend 2016). We find that 87 percent of the angel investors are male. This gender ratio is in line with existing research on angel investors. Ewens \& Townsend (2018) find that 92 percent of angel investors on AngelList are male. In a wide survey of

in any case the investment has to be completed before the tax credit is issued. Anecdotal evidence seems to confirm this hypothesis. 
U.S. angel investors, most of whom are members of the Angel Capital Association, Huang et al. (2017) report that 80 percent are male. Gompers \& Wang (2017) find that around 90 percent of VCs are male. We coded the ethnicity or race using pictures, and found that 95 percent of investors appear to be white. ${ }^{19}$ In Huang et al. (2017)'s data, 87 percent of respondents are white. Panel 2 of Table 3 shows that the average angel investors is 42 years old. The average age is higher in Huang et al. (2017)'s data, at 58 years old.

We also categorized job titles or descriptions: The majority of investors are corporate executives (e.g., the Vice President of a company). The next-largest group is doctors, at 7.3 percent. There are relatively few professional investors or entrepreneurs. Among survey participants in Huang et al. (2017), 55 percent report being executives at for-profit companies, and 55 percent also report experience with entrepreneurship. Therefore, our data appear more heavily weighted towards executives at older companies and away from entrepreneurs.

Together, these statistics paint a novel portrait of angel investors in non-hub states. This provides an alternative window into the sector, contributing to existing survey evidence in Huang et al. (2017) and data about AngelList platform participants in Bernstein et al. (2017) and Ewens \& Townsend (2018). Specifically, angel investors who receive tax credits in non-hub states appear younger, less entrepreneurial, and whiter than the average U.S. angel investor.

\subsection{Data on applicant companies}

We obtained data on beneficiary companies for 12 states either from public records or from privately from state officials (which include the seven with investor data in Section 2.2). For 10 of these states, we also observe companies that were certified to have an investor benefit from a tax credit, but for which no investor actually was awarded a tax credit. We term these "failed applicants." The data for the 10 states span 2005-2018. Within a given

\footnotetext{
${ }^{19}$ We also coded as Hispanic individuals that our web researchers identified as "white" but who had names among the top 20 Hispanic names in the U.S. (https://names.mongabay.com/data/hispanic.html).
} 
year, the data are comprehensive, though we do not always observe all years from program inception. Table 2 Panel 1 shows the number of unique companies by state. The state with the largest number of companies is Ohio, with about 900, and the smallest is New Mexico, with 72. In total, there are 1,823 beneficiary companies (for which an investor received a tax credit), and 1,404 failed applicants (certified yet no investor claimed a credit).

There are two reasons that a company would be in the "failed applicant" category. First, it is possible that no investment deal occurred. ${ }^{20}$ Second, the company may have applied after the state ran out of funding but before it closed its application portal (many states have a first-come first-served policy). If no deal occurred, the company may have sought but failed to raise angel investment or raised it from some other source that is not eligible or chose not to claim the state tax credit. If the company was later than other startups in applying and the state had run out of money, there is no reason to expect that it is better quality. If anything, we may expect "late" companies to be worse. Therefore, it is reasonable to assume that if there is bias in comparing these groups it should be in the direction of beneficiary companies performing better than failed applicants. We will come back to this discussion as we present the tests later in the paper.

We merged unique tax credit recipients to two external datasets. The first is a dataset of angel and VC equity financing events, which we refer to as the "financing data." These financing data combine deal-level data from VentureXpert, Crunchbase, and CB Insights. ${ }^{21}$ We match startups in the tax credit data to the financing data by name and state location. The second external dataset is Dun \& Bradstreet (D\&B), which is a panel dataset at the company-year level. ${ }^{22}$ Startups in the tax credit data are matched to startups in the D\&B data by name, state, and city of headquarters location (if available). We matched 808 companies to D\&B and 1,227 to the financing data. There are 608 firms that matched to both. We developed startup sector classifications based on market and industry variables in

\footnotetext{
${ }^{20}$ In some states there is no time limit on when a qualified business can receive a investment that can claim a tax credit, while in other states it is limited to one year (see column 25 in Appendix Table A.1).

${ }^{21}$ We do not include AngelList in the financing data because there are no funding amounts and no specific dates for many investments. That is, there is a year but not the exact date to ascertain when the investment occurred relative to the tax credit award.

${ }^{22}$ The original D\&B is at the establishment level. We merge the tax credit data to establishment names, then aggregate to the company-level for analysis. Most companies in the tax credit data have only one establishment in D\&B.
} 
the financing and D\&B data, as well as hand-coding.

Table 2 Panel 2 shows that beneficiary companies are on average more successful than their rejected counterparts. Any Financing Pre-TC indicates whether a startup received financing before its tax credit year. Any Financing 2 Years Post-TC indicates whether a startup received financing within two or three years after its tax credit year, including the tax credit year. The amount of financing is defined analogously. Beneficiary companies raise previous financing at nearly twice the rate of failed applicants. The dollar amount of previous financing is $\$ 3.3$ million for beneficiary companies, relative to $\$ 2.5$ million for failed applicants. We return to the subject of past financing in Section 4.2.1, where we discuss the mechanisms behind our results. After the tax credit year, beneficiary companies are more likely to raise additional financing, raise more money, and are more likely to exit than failed applicants. These features are discussed in detail in Section 4.1.

Employment data comes from D\&B. We are primarily interested in whether the number of employees at a startup exceeds various thresholds during a tax credit year and in the years that follow. We create indicators for whether startups employ greater than 10 or 25 employees, which are reasonable benchmarks for small businesses, and whether the number of employees exceeds the sample's 75 th percentile. One reason we bin the employment outcomes is that not all D\&B is precise, and imputation can create bias (Barnatchez et al. 2017). D\&B provide flags for the source of employment data: true value, range, impute. In our data, employment is "true" data for 72 percent of firms. ${ }^{23}$ Emp $>x$ in Credit Yr indicates whether the number of employees exceeds $x$ in the company's first tax credit year. Thirteen percent of companies have more than 10 employees and 4 percent have more than 25 employees. These numbers rise somewhat in the second year after its first tax credit year (Emp $>x$ 2yrs Post-TC). Table 2 Panel 2 shows that there is no difference in employment between beneficiary companies and failed applicants either before or after the tax credit year.

\subsection{State-level outcome data}

We use four datasets to examine the effects of the policy at state level. First, we construct state-level annual time series on the activity of angel investors. We use the total number

\footnotetext{
${ }^{23}$ Given the potential noise in the data, we use binned categories.
} 
of angel investor deals in the state and the number of unique investors in a comprehensive dataset representing the entire AngelList platform as of July 2019. While AngelList is in large part self-reported, it is the most comprehensive source available about specific angel investments such that both the investor and company location are both observed. However, a downside of AngelList is that there is no information on the deal amount. For the amount of investment, we rely on the financing data (from several standard commercial databases, described in Section 2.3). One issue with amount variables is that they may reflect one or two firms receiving a large amount of money, rather than the overall number of new, potentially high-growth firms that is the main goal of the policy.

Statistics on our outcomes of interest are in Appendix Table A.2. Specifically, "Number of Angel Deals" is the number of unique deals in the state-year. "Number of Angel Investors in Local Companies" is the number of unique individuals that have at least one investment in that year in a company located in the state. Similarly, "Number of Angel Investors from State" is the number of unique individuals who are themselves located in the state and made at least one investment in any company in the year.

Our primary outcomes of interest to capture the ultimate goal of the tax credit programs - real effects of local new firm growth - come from public use Census data. First, we use information on the aggregate employment in young entrepreneurial firms using data from the Quarterly Workforce Indicators (QWI). The QWI allows us to measure both aggregate and industry employment for firms of different ages and sizes. We construct the data at annual state level (end-of-year) since the policy variation is at the state-level. Appendix Table A.2 reports a summary of the QWI data. We consider firms less than five years old in our main outcome variables as five years old is typically the maximum age for eligibility in states that have an age criterion (see Section 2.1). We also focus on startup employment in manufacturing or high-tech industries, which are the focus of the tax credit programs. ${ }^{24}$

Unfortunately, the QWI does not include the number of firms. To consider this dimension, we use the County Business Patterns dataset. As these data have no breakdown by age, we

\footnotetext{
${ }^{24}$ QWI data is provided with a breakdown by industry and we define high-tech industry. To be clear, our main employment variable is the sum of employment in young firms that is either in manufacturing or in the high-tech industry. Following the definition in Appel et al. (2017), which use similar data, the high-tech industry covers both life-science and IT and it contains the following NAICS: 32543341334233443345 , $3346,3353,3391,5112,5141,5171,5172,5179,5182,5191,5413,5413,5415,5416$ and, 5417.
} 
proxy for the activity of target firms by focusing on the number of establishments of small businesses with less than 20 employees in the high-tech and manufacturing industries. ${ }^{25}$ These real effect outcomes are also summarized in Appendix Table A.2.

\section{Tax Credit programs and state-level activity}

State tax credit programs aim to increase local employment and economic activity by encouraging higher volumes of early stage investment in high growth companies. The first step in our analysis is to examine state-level data for evidence of success. After describing the empirical approach (Section 3.1), we describe the results for angel investment and real economic outcomes (Sections 3.3 and 3.2).

\subsection{Empirical Approach}

To test for a possible positive effect of these programs, we use a difference-in-differences model, which exploits variation across time and states in the program availability. Variation across states comes from the programs' staggered introduction and closure. ${ }^{26}$ In particular, we estimate the following equation:

$$
y_{s t}=\alpha_{t}+\alpha_{s}+\beta T C_{s t}+\theta X_{s t-1}+\varepsilon_{s t} .
$$

Here, $s$ identifies the state, and $t$ is the year. The coefficient of interest is $\beta$ on an indicator for whether or not a state has a tax credit program in a given year $\left(T C_{s t}\right)$. In the main specifications, we use a set of state-by-year controls, $X_{s t-1}$, which include the log of population, the log of personal income, the level of corporate income tax, and the unemployment rate, all of which are lagged by one year. ${ }^{27}$ As the outcome data for both

\footnotetext{
${ }^{25}$ According to the UNH 2017 Angel Market Report, 30 percent of all angel deals are in software, and 29 percent are in life sciences; see https://paulcollege.unh.edu/sites/default/files/resource/files/2017-analysisreport.pdf.

${ }^{26}$ We identify the start year based on information contained in state program documentation, where we define the beginning of a program as the year the program starts, or the year after if the start date is in the second half of the year (see Table 1 and Appendix Table A.1).

${ }^{27}$ We discuss later also results without controls, to address issues related to endogenous controls in panel analysis (e.g. Angrist \& Pischke 2008).
} 
angel investments and employment (QWI) is sparse in earlier years, we restrict to the years from 2002 to 2016. All outcome variables $Y_{s t}$ are transformed to log plus one (i.e. $y_{s t}=\ln \left(Y_{s t}+1\right)$, both to linearize skewed variables and to ease interpretation.

In the main analysis we exclude Massachusetts and California, because they are outliers in terms of both angel investment and high-tech job growth during our period and never used angel tax credits. This raises the concern that their inclusion would bias against finding an effect of the policy. In a robustness test discussed below, we show that this restriction does not significantly affect the magnitude of our results, and if anything, it actually increases the noise in the estimates. Last, standard errors are clustered at state level, which is the level of the treatment. In the first part of our analysis, we report confidence intervals rather than standard errors to be more transparent about the possible upper bounds of the effects, as part of our findings are null effects.

In general, a causal interpretation of these results requires that the staggered introduction to the programs is exogenous to the development in the local start-up and angel ecosystem. While this hypothesis is fundamentally untestable, there are a few steps we take to provide evidence consistent with it. First, a qualitative analysis of the introduction decisions does not suggest any systematic patterns in the adoption of these policies. Given the type of intervention, this result is not surprising. As we discussed before, these programs tend to be small relative to the overall budget of the state. Therefore, they appear to respond more to idiosyncratic political pressure rather than any systematic change in the economy of the state. Also, to the extent that these policies respond to changes in state-level economic activity, our lagged controls directly control for them. Finally, we conduct two tests. The first examines timing of effects around the program introduction. The second adds Census division by year fixed effects, which restricts control states to those that are located nearby and plausibly in more similar conditions. More discussions on these tests is provided later.

While we believe that this approach is a reasonable first step towards estimating the effects of these policies, we want to emphasize that a more descriptive interpretation is also valuable. This is because while we find no meaningful effects on the real economy, the most likely sources of endogeneity should bias estimates upward. States tend to employ them when they are more broadly trying to encourage the development of entrepreneurial ecosystems. 
Also, the policies are not on average implemented during business cycle contractions, as we discuss later when we examine the timing of our effects.

\subsection{Effects on Aggregate Employment}

The programs' main objective is to increase local economic activity. In Table 4 Panel 1, we show effects on two measures of employment among firms no more than five years old: total employment and employment in the industries that are sometimes targets of the programs, manufacturing and high-tech. We prefer the total employment outcome, because in practice beneficiary companies tend not to be high-tech or manufacturing (Section 4.2), and total employment will include any potential spillover to the rest of the state economy in cases where a program does target specific sectors.

We find no evidence that the tax credit had a meaningful impact on economic activity. Not only are the measured effects not significantly different from zero, but they are also small in size. Here the 95 percent confidence intervals are especially useful. In column 1, the coefficient on total employment of 0.005 implies a 0.05 percent increase, with an upper bound of 3 percent. Column 2 finds a slightly noisier but also insignificant effect for high-tech and manufacturing employment. The results are similar when these two economic areas (hightech and manufacturing) are considered separately. Since we do not have data on number of establishments by age, we next look at the effect on number of small business establishments, focusing on manufacturing and high-tech. ${ }^{28}$ Column 3 finds an effect of -0.9 percent, with an upper bound of one percent for manufacturing. The result is similar for high-tech.

Altogether, our evidence fails to provide support to the claim that tax credit programs were associated with meaningful increases in local entrepreneurial activity. ${ }^{29}$ This null effect is not driven by trends around the decision. To establish this, we estimate a separate coefficient for each year around the implementation year and graph these coefficients in Figure 2. ${ }^{30}$ The plots show a null effect before and after the policy implementation year. The

\footnotetext{
${ }^{28}$ The results are similar for all firms, though these seem less relevant as they will include many old subsistence businesses (old and small firms).

${ }^{29}$ If we use an alternative clustering - i.e. state by year - we generally get smaller standard errors, though still finding non significant effect. Therefore, our choice of state-level clustering, on top of being conceptually the right approach also provides more conservative estimates of the errors.

${ }^{30}$ States that never introduce a tax credit program are always recorded in the pre-shock period, in the
} 
absence of a negative trend in pre-period suggests that the programs were not systematically implemented during troughs in the business cycle.

\subsection{Effects on Angel Activities}

We next turn to angel activity in the state. We consider four dimensions of the state's angel ecosystem as outcome variables, and continue to use Equation 1 for estimation. The results are presented in Table 4 Panel 2. The introduction of the tax credit is associated with a 30 percent increase in the number of angel deals and number of investors in local companies (columns 1 and 2). When we consider the number of unique angel investors that are from the state, we find an effect of about 19 percent (column 3). This is not surprising since most of angel investors tend to invest in the same state. ${ }^{31}$ These positive effects exist in variables derived from the AngelList platform, which relies on individuals self-identifying as angel investors. That is, while we call these time series "angel", they do not necessarily imply angel investment in the sense of being seed investment in a potentially high-growth startup that does not have access to traditional sources of financing. The coefficient on the amount of angel investment (column 4) is positive but insignificant. ${ }^{32}$ We also find insignificant effects when we include all types of early investment, including incubators and grants, and when we include early stage (Series A) VC investment.

It appears that the tax credit programs may increase the number of deals and investors involved. We examine the timing of effects to shed some light on what is happening, as previously discussed. As shown in Figure 2, there is no significant trend in the pre-period number of deals or number of investors, which suggests that these policies are not introduced when the state is experiencing the negative part of the economic cycle. Consistent with the positive results discussed above, the coefficients are above zero starting in the year the program was introduced. However, the effect is only significant at the 5 percent level in the year of implementation. ${ }^{33}$

earliest time group.

${ }^{31}$ From a policy perspective, the preferred variable is the number investing in local companies, which includes individuals out of state. In particular, it is important to recall that they may still benefit from the credits, as most states will offer cash if there is no state income tax liability.

${ }^{32}$ We restrict analysis with the financing data to post-2008, as earlier deals are relatively rare.

${ }^{33}$ In regressions, the effect is significant at the 10 percent level for the coefficient on the indicator for at 
We conclude that the tax credits likely positively impact the number of new deals happening in the state as well as on the number of investors that are involved in angel investment. However, to the degree these results are robust, they appear to have been temporary.

\subsection{Robustness}

We conducted a wide variety of robustness tests to confirm the null effects. Here we will show critical tests and briefly describe others.

In Appendix Table A.3 we report three additional specifications for the key outcomes. The first omits all controls, in case they bias estimates towards finding no effect. Instead, there continues to be no effect even on the measure of employment that had yielded the largest magnitude in our main specification (column 1), and the positive effects on angel investment grow slightly larger (columns 4 and 7). Second, we also show that our results remain similar with Census division by year fixed effects, which compares states within the same Census division (columns 2,5 and 8). The intuition is that states in the same division likely have similar economic characteristics. Finally, in columns 3, 6, and 9 we include California and Massachusetts, which have never had tax credit programs and have much larger entrepreneurial ecosystems than other states. The results are noisier, with the effect on angel investment activity becoming insignificant. However, the magnitude of the key parameters is similar.

In Figure 3, we use simulations to better benchmark the size of our main results to the effect we would estimate under the assumption that tax credit had no impact. For each of our four main outcomes - employment in young firms, employment in young firms in hightech or manufacturing, number of deals, and number of investors in local companies - we create 1,000 placebo trials by assigning the tax credit dummy at random among states and years. ${ }^{34}$ We conduct this procedure across the three specifications discussed in the paper so far: the baseline model, a model without controls, and a model augmented with division by

least three years after introduction.

${ }^{34}$ The only constraint we impose is that the number of tax credit active (state and year level) is the same as in the real data. 
year fixed effects. In Figure 3, the black dots represent the placebo coefficients, and they show that as expected, on average a policy induced at random has no effect on any of the outcomes. At the same time, as expected, for some of the random draws the placebo policies do have large effects.

Our main objective is to compare our estimates of the true effect to the placebo distribution. In general, this comparison confirms our main results. The estimated parameters for real outcomes is generally close to zero, rather than in the tails of the placebo distribution. The one exception is the baseline specification for employment in high tech or manufacturing. However, this result is not robust, because the estimated true coefficient in both the other two specifications is close to zero relative to the placebo distribution. In contrast, for angel financing outcomes, the estimated coefficients are consistently in the top one percent of the distribution, across both measures and all the specifications.

In unreported tests, we found no effects on economic activity at the Metropolitan Statistical Area (MSA) level, which might have increased precision of a positive effect. For both MSA and state-level analysis, we find no meaningful heterogeneity. For example, there is no effect when we interact the tax credit with measures of the quality of the entrepreneurial ecosystem (e.g. level of preexisting angel investment). We also find no

effects on a number of other outcome measures, including VC investment, other types of early investment (e.g. grants and accelerators), and economic activity in other specific sectors such as IT or life sciences. Finally, we find no effects by intensity of the program; that is, the effects are not larger when allocated funding or take-up is large relative to local angel investment.

\section{Mechanisms}

For these programs to be effective, the tax credit needs to induce firms to make investments that would have not happened otherwise. The results in Section 3 suggest that the state angel investor tax credit programs have failed to achieve the primary objective of increasing real economic activity, though we find some evidence of increased angel activity. The first and 
more positive interpretation is that these programs were too small to generate a positive effect that is detectable in aggregate (scale hypothesis). A second mechanism is that the program did motivate new seed investment, but there was no pass through to real firm investment in human or physical capital, and therefore no growth effects. This could occur, for example, if the company substitutes bank debt with angel investment. In other contexts, there is evidence that increases in credit or other types of financing do not yield pass through to investment (Dharmapala et al. 2011, Yagan 2015). In this channel, we expect that beneficiary companies are not especially financially constrained.

A third and related mechanism is tax arbitrage. Here, the programs induce little or no new angel investment in the sense of being additional seed investment in startups. While investors receive a benefit as a result of the credit, beneficiary company activity is unchanged. This could occur in a number of ways. For example, an investor who is a family member of the entrepreneur may now use the tax credit and label himself an angel investor. Both the explanations of low pass-through and tax arbitrage point to faulty program design, in the sense of failing to screen out firms with low sensitivity to the subsidy. We refer to this interpretation as the "design hypothesis."

In this section, we proceed in three steps. First, we use firm-level evidence to show that even among beneficiary companies, there is no apparent effect of the tax credit on growth. As we discuss below, this result would be hard to square with an explanation that only relies on the small size of the program. Second, we examine characteristics of companies and investors who make use of the tax credits. This analysis will provide direct evidence in line with our design hypothesis. Third, we discuss why firms that may have actually benefited from the programs - constrained firms with good investment opportunities - did not participate to it.

\subsection{Firm-level analysis}

If the small scale explains the result, then we may think that the programs are working well and - if anything - states should simply increase their scale. To explore whether scale might be the problem, we ask whether the companies that specifically benefited from having an investor receive a credit appear to have been more successful as a result. We use data at the 
firm level about the specific beneficiary companies relative to certified applicants for which no investor received a credit. We expect that if the tax credits enable them to raise more seed money than they would have otherwise or raise money where they would not have been able to at all, they will subsequently perform better in terms of follow-on VC financing and employment. In this section we use two estimation approaches to analyze the relationship between being a beneficiary company and outcomes (Sections 4.1.1 and 4.1.2).

\subsubsection{Within-program analysis}

This section uses data only on certified companies - companies that demonstrated interest in having an investor receive a state angel investor tax credit - to assess whether being a beneficiary company is associated with better outcomes. Specifically, we estimate the effects of angel investment tax credits on startup success by comparing financing and employment outcomes for beneficiary companies and companies that were certified but failed to have an investor receive a tax credit ("failed applicants", see Section 2.3 for details). The intuition behind this test is simple: as discussed above, there is no reason to think that companies that applied for the tax credit but failed are of better quality than recipient firms. If anything, the "failed" companies are likely worse quality. As a result, if the tax credit has any positive impact on firms' activity, we should expect to find that recipient firms outperform the control group in the future.

We use variants of the following equation:

$$
Y_{i, t+k}=\alpha_{t c}+\alpha_{t s}+\beta T C_{i}+\delta^{\prime} \mathbf{X}_{i t}+\varepsilon_{i, j}
$$

The dependent variable $Y_{i, t+k}$ is a financing or employment outcome for startup $i$ in year $t+k$, for $k=1,2,3$, where year $t$ is the "tax credit year" — the year the startup either received its first tax credit or first unsuccessfully applied for a tax credit. $T C_{i}$ is an indicator for whether startup $i$ received a tax credit or was denied a tax credit. In $\mathbf{X}_{i t}$, we control for the preexisting level of the outcome variable, which is either previous financing or employment in the application year. Our most stringent specification further includes sector-year fixed effects $\left(\alpha_{t c}\right)$ and state-year fixed effects $\left(\alpha_{t s}\right)$. In all cases, we cluster standard errors by state-year. 
The sample is restricted to the 10 states in which we observe all certified companies. ${ }^{35}$

The relationship between receiving a tax credit and subsequent financing is shown in Table 6. For an angel-funded startup, a useful proxy for subsequent success is raising VC. Therefore, our preferred outcome is an indicator for raising $\mathrm{VC}$ within two years following the tax credit application year (Panel 1). As predicted in the summary statistics, with no controls beneficiary companies are about ten percent more likely to raise VC (column 1). However, this relationship disappears when previous financing is controlled for (columns 2-5). In our preferred specification with state-year and sector-year fixed effects in column 5 , the coefficient is -0.88 percentage points, with a 95 percent confidence interval ranging from -4 to 2 percentage points. The average rate of subsequent VC is 21 percent, so even the top of the confidence interval would be just 10 percent of the mean. Table 6 Panel 2 considers other financing outcomes: the log amount of external financing raised in the two years after the tax credit year (columns 1-2), the level amount (column 3), and the chances of an exit through IPO or acquisition (columns 4-5). In all cases, we find effects that are not significantly different from zero after controlling for previous financing.

We next turn to employment. Table 7 Panel 1 examines our preferred outcome, which is an indicator for having at least 25 employees in the second year after the tax credit year, which has a mean of about three percent. The effect is 1.1 percentage points with no controls (column 1), but is -0.021 percentage points in our preferred specification, with a 95 percent confidence interval ranging from -0.5 to 0.5 percentage points (column 5). Across the range of specifications with alternative controls, we find persistently negative coefficients that are very close to zero. Panel 2 demonstrates that the same is qualitatively true using alternative outcomes: at least 10 employees (columns 1-3), and employment greater than the 75th percentile among certified companies (columns 4-6). We conducted a range of robustness tests for these results, including alternative control specifications and interactions with state characteristics. $^{36}$

\footnotetext{
${ }^{35}$ In general, there are too few clusters to take seriously errors clustered by state, as this sample includes only 10 states. However, the results are very similar with other approaches, including robust standard errors.

${ }^{36}$ We find no effects in obvious subsamples, such as states that tend to run out of money. In these cases, firms that did not receive the tax credit are more likely to be comparable to recipient companies, since the time in which money runs out could be thought as as-good-as random. Also in this case, for both financing and employment, we can rule out economically meaningful positive effects of being a beneficiary company.
} 
In sum, tax credits for investors do not lead beneficiary companies to raise more money or grow more than certified companies for which no investor received a tax credit. These results are surprising because bias should push toward a positive effect among beneficiary companies relative to failed applicants. However, the findings are consistent with the aggregate results above. The unconditional increase in future funding is in line with the programs' positive impact on local angel activity. At the same time, the null effect once we control for previous funding is consistent with the absence of real aggregate effects, and points towards a crowding-out mechanism. Indeed, a large share of the companies receiving the tax credit were already able to raise money. That is, while firms receiving the tax credit seem to outperform the control group, this is entirely driven by positive selection. We will come back to this later.

\subsubsection{Matching estimator}

This section provides an alternative approach to assessing the performance of beneficiary companies. Instead of comparing them to failed applicants, we compare them to control firms in nearby states without tax credit programs, which therefore couldn't plausibly apply for a tax credit. Here, we can use all tax credit recipients in the potential treatment group. First, we restrict the sample to startups observed in both the financing data and the D\&B data. Then we match each treatment group startup with up to five similar control group startups through a nearest neighbor matching procedure (e.g. Bernstein et al. 2018). To match with a treatment group startup, the control group startup(s) must be located in a different state but the same census division, belong to the same sector/market, have a similar age, and have a similar amount of previous financing relative to the year of the treatment startup's first tax credit. ${ }^{37}$ After this match, the age of each control group startup must be within two years of the treatment group startup's age, and each startup belongs to one of eighteen narrowly defined sectors. Covariates before and after matching are shown in Appendix Table A.4.

Within the nearest neighbor match group consisting of one treatment startup and up to

\footnotetext{
${ }^{37}$ Based on the within-program analysis above, it is clear that having raised a similar amount of previous investment is a crucial control, so we match on this rather than using it as an outcome.
} 
five control group startups, we measure outcomes with respect to the year of the treatment group startup's first tax credit; we refer to this as the "tax credit year" for both treatment and control group startups in a match group. We use variants of the following equation, where variables are defined analogously to Equation 2 above.

$$
Y_{i, t+k}=\alpha+\beta_{1} T C_{i}+\beta_{2} Y_{i, t}+\delta^{\prime} \mathbf{X}_{i t}+\varepsilon_{i, j}
$$

Note that we control for startup $i$ 's pre-tax credit year performance with $Y_{i, t}$, and in some models startup-specific characteristics with $\mathbf{X}_{i}$. These include sector-year fixed effects as well as an indicator for whether the startup previously raised private investment.

Like the within-program analysis, the matching estimator finds near-zero and often negative coefficients on the relationship between receiving a tax credit and subsequent employment or startup exit. The results are in Table 8. Our preferred specification for employment, in Panel 1 column 4, finds an effect of -0.64 percentage points relative to a mean of three percent, again indicates the absence of a meaningful positive effect, though the result is somewhat less precise than the within-program analysis. In this case, the 95 percent confidence interval ranges from -2.5 to 1.2 percentage points. The rest of the table confirms these findings, showing near-zero effects on employment higher than ten or higher than the 75th percentile (Panel 1 columns 1-2 and Panel 2 columns 1-2), and on the chances of exit (Panel 2 columns 4-5).

\subsection{Explaining the Null Result: The Nature of Take-up}

The analysis in Section 4.1 demonstrates that absence of a state-level effect does not reflect a small effect size, allowing us to rule out the scale hypothesis. As discussed above, the second possible mechanism is that the programs were taken up by firms that did not conduct real additional investment after having an investor receive a credit. If this mechanism is the primary driver, we should expect that beneficiary firms are less likely to be financially constrained ex-ante and operate in areas where raising traditional funding is relatively easy. ${ }^{38}$ Another alternative is that low responsiveness may reflect firms using the credits solely for

\footnotetext{
${ }^{38}$ The intuition is that if a firm is unconstrained, then it should be less responsive to cost of capital.
} 
tax arbitrage and rent seeking. If this is the case, we expect to find that a large share of investors are insiders of the firm, who are in a privileged position to undertake this strategy.

\subsubsection{Pre-existing investment}

Our first observation is that beneficiary companies tend to already be well-financed, a result that would help explain the relatively low pass-through. As shown in Table 2, nearly forty percent of the beneficiary companies previously received external financing, with an average of $\$ 3.7$ million conditional on having received previous financing. These dollar amounts are large relative to the average angel deal size, which was $\$ 390,000$ in $2017 .{ }^{39}$ Startups seeking financing on AngelList request on average $\$ 700,000$, and just 2.6 percent of these startups are successfully funded (Ewens \& Townsend 2018). Our rate of matching to external financing may be biased downward as the financing data do not comprehensively cover early stage, especially angel, investment. Furthermore, the average investment amount that benefits from a tax credit is $\$ 376,000$, also much higher than the average U.S. angel check, which according to Huang et al. (2017)'s survey is $\$ 35,000$. This evidence suggests that a sizable share of firms that received the tax credit may have been able to raise funding independently from the program.

If these firms were indeed able to raise funding independently from the program, then the tax subsidy should not have any real effect for the business. ${ }^{40}$ Rather than being the "first money in," the investment that benefits from the tax credits tends to come after substantial funding. Consistent with previous financing helping to explain a crowding out mechanism, we found in Section 4.1 that null effects depend on a control for previous financing.

\subsubsection{Sector composition}

Our second observation concerns industry composition. We expect that subsidies will be most useful for financially constrained companies, which are typically those characterized by high information asymmetry (Howell 2017, Howell Forthcoming). We also expect that the

\footnotetext{
${ }^{39} \mathrm{See}$ UNH Center for Venture Research Angel Market Report 2017, available at https://paulcollege.unh.edu/sites/default/files/resource/files/2017-analysis-report.pdf.

${ }^{40}$ It seems unlikely that there are no financially constrained and eligible startups in states that adopt the tax credits, given the abundant evidence of constraints (e.g. Kerr \& Nanda 2011, Howell Forthcoming).
} 
programs will increase growth if they target potentially high-growth startups, rather than the average small business that does not tend to grow very much (Schoar 2010, Haltiwanger, Jarmin \& Miranda 2013).

We explore this hypothesis by comparing the industry composition of beneficiary companies to that of VC-backed companies. Figure 4 groups beneficiary companies into five sectors and compares their sector distribution to that of VC-backed companies. ${ }^{41}$ Since the tax credit data span 2005-2018, this is the same period we use to identify unique VC-backed companies. We require them to have a first VC deal date in the same period. The sector most strongly associated with VC backing and Silicon Valley is what we term "IT/Web/Computer," which includes companies whose activities are primarily related to software, mobile, web, or computer hardware. Sixty-five percent of VC-backed companies are in this sector, according to their primary categorizations in the financing data. We try to be as generous as possible in assigning applicant companies to this sector, assigning them if there is any evidence of activity in this area from any of the sector/market/industry variables in the financing and D\&B data, as well as by manual search.

Among beneficiary companies, just 27 percent are in the IT/Web/Computer sector. ${ }^{42}$ The other sector with a large difference is "Other," with 25 percent of companies. This includes local businesses in sectors that are not typically associated with growth, innovation, or angel investment. Examples of companies in this category include a hoof trimming business in Ohio and an art store in Wisconsin. Our sector evidence may appear to contrast with program rules in many states that seek to limit eligibility to high-growth industries. It seems that a wide variety of companies successfully claim in their application that some aspect of what they do is, for example, "IT-related." Operating in more traditional sectors also implies that these firms may be also able to access traditional financing, such as bank loans, and thus should have less need for subsidized angel investment.

Many companies in our data - including some in the "Other" category - are potentially high-growth businesses. However, these businesses tend to have raised previous financing before the round in which they had an investor benefit from a tax credit. When the sample is

\footnotetext{
${ }^{41}$ We use the Crunchbase and CB Insights databases.

${ }^{42}$ Table 2 shows that beneficiary companies are somewhat more likely to be in this sector than failed applicants, again pointing to the potential for positive bias in the within-program analysis.
} 
restricted to companies without previous financing, the share in IT/Web/Computer declines to just 16 percent, while the share in Other rises to 35 percent. Furthermore, applicant companies in the high growth sectors are much more likely to have had previous financing, and thus are likely less constrained than companies seeking to raise a first round. Among all applicant companies, 26 percent had previous financing before their tax credit year. Among IT/Web/Computer companies, 51 percent raised previous financing. The analogous percentages for beneficiary companies are 37 and 64 percent. In sum, it appears that the tax credit programs tend to be used by companies that are either not in especially high growth sectors or had previous financing.

\subsubsection{Insider investment}

The third observation is that a large share of investors receiving tax credits are employees or executives of the beneficiary companies. These insider investors face smaller financing frictions than external investors; specifically, they have no information asymmetry or agency problems in the conventional senses. For an insider investor, it is not clear how the tax credit might address market failures. Instead, high take-up by insiders also points to crowding out, where the subsidy serves as a transfer from the local government to the investor. ${ }^{43}$

We conduct this analysis in the five states where we observe the identities of tax credit beneficiary companies, the names of investors that were awarded tax credits, and the link between these two pieces of information (Ohio, New Jersey, Maryland, New Mexico and Kentucky). There are 628 unique companies in this group, and 3,560 investors. We took three approaches to identifying insiders among tax credit recipient investors. The first examines whether the investor reports being employed at the company on LinkedIn. Among investors for whom we observe LinkedIn employment histories, 20 percent identify as employed at the company they invested in during the time period in which they received the tax credit, of which almost half are the CEO (shown in Panel 1 of Table A.5).

The second approach to studying owner-manager investment examines whether investors also appear as executives on SEC Form D filings. Private equity issuers must file Form D with

\footnotetext{
${ }^{43}$ It is important to point out that subsidizing insiders is not always and necessarily a bad idea. To the extent that private would invest less than the social optimal amount, then the subsidy could potentially raise welfare. However, this mechanism would also require some respose in terms of real activity.
} 
the SEC to be exempt from registering the issue as a security, which would essentially require an IPO. For this reason, the vast majority of angel and VC investments are accompanied by a Form D filing. We were able to find Form D filings in the year of the tax credit for 186 of the companies, and we matched executive officers from the Form D to investors in the tax credit data. ${ }^{44}$

The third approach was to use last names. We first identified the 61 companies that had at least three investors with the same last name (see Panel 2 of Table A.5). For these investors, we searched websites to identify if they or a family member were an executive. Based on this process, 61 percent of these 61 companies were identified as having an insider investor (Panel 3 of Table A.5).

After eliminating duplicate owner-managers across the three methods, our final results are in Table 5. We find that 35 percent of the companies for which we observe the investorcompany link have at least one investor who is an executive or family member of an executive, and 33 percent have an investor who is an executive. The share is 24 percent or above in all states but Kentucky, where it is just four percent. Interestingly, most states explicitly permit the investor to be employed at the company (see Appendix Table 1 column 27). Given the difficulty of identifying insider investors, we believe that our calculations likely underestimate the true magnitude of the phenomenon.

One further sign that the policies may not be targeting the "right" investors is the discrepancy between professional backgrounds in our data and characteristics that Huang et al. (2017) find to be associated with investment success. The majority of angels in their survey have past entrepreneurial experience (i.e., founded a company). They find that these "entrepreneurial" angels invest in more companies, take a more active role in their portfolio companies, and have superior returns. In our data, only six percent of investors benefiting from tax credits identify themselves in their LinkedIn career history as an entrepreneur or

\footnotetext{
${ }^{44} \mathrm{~A}$ company must list its executive officers and board members in its Form D. We matched our companies to SEC Form Ds available on https://disclosurequest.com, which are those post-2010 when the Form Ds are available in HTML (rather than PDF). Of the 628 unique companies, we were able to match with certainty (i.e. no false positives) 186. We use the Form D filed in the year of the tax credit. There are 407 unique executive officers on these Form Ds, and of them, there are 38 with the same full name as an investor who received a tax credit, and an additional 24 with the same last name as an investor. Of the 186 matched companies, 39 have at least one investor who is an executive or family of an executive. The share of investors implicated is small, as the companies that match tend to have a large number of investors.
} 
co-founder (Table 3).

The high prevalence of owner-managers benefiting from the tax credit sheds helps explain the absence of an effect, as these insiders seem likely to have invested in the absence of the program. Our findings relate to existing work on tax avoidance (Slemrod \& Yitzhaki 2002). Gordon (1998) suggests that one explanation for entrepreneurial entry may be tax avoidance, as individuals with high incomes have an incentive to reclassify income as corporate rather than personal. In our setting, owner-managers may identify as angel investors in order to benefit from angel tax credits.

\subsection{Discussion}

The channels above of insider investment, low-growth companies, and pre-existing investment are consistent with the idea that individuals and firms who took advantage of the tax credit programs were not meeting the two requirements for an impactful program: making additional investments relative to would have happened anyway, and investing in new, constrained firms with the potential for growth. Note that the three channels are not mutually exclusive and, indeed, overlap in the data. It is useful to consider the share of companies that they encompass. Among beneficiary companies, 63 percent of companies had not already raised equity based on the match to external financing data. Of these, the majority are either not in the high growth potential sectors of Biotech and Computer/Info Tech or have an investor who is a company manager. Just 9.5 percent of beneficiary companies have the characteristics we expect a successful high-growth startup subsidy would target: no insider investment, in the IT/Web/Computer sector (which disproportionately receives $\mathrm{VC}$ and generate high-growth, innovative companies), and with no previous external equity.

These results point towards the design hypothesis. However, there are two puzzles that remain. The first one is that we observe an increase in angel activity using AngelList data. This points to the possibility that "true" angel seed investment increased but there was no pass-through to real activity. The alternative is a re-labeling explained by tax arbitrage. To explore this, we assess whether our estimates are in large part explained by an increase in investors that are less likely to be considered as "true" angels in the sense in which they are 
usually described in the literature (e.g. Lerner et al. 2018).

To investigate the type of investor driving the increase, we divide the number of angel investors in local companies (the dependent variable in Panel 2 column 2, where we see the largest effect) into two types: professional and non-professional. If the programs are driving new "true" angel investment in startups, we expect professional investors to drive the increase. In contrast, if one-off investments by individuals who are often themselves executives or family members of executives are driving the increase, and they are labeling themselves angels on AngelList, we expect non-professional investors to drive the increase.

The results are in Table 4 Panel 3. Professional investors in columns 1-2 are defined as having at least two deals in the year. In columns 3-4, they are defined as having at least one exit (IPO or acquisition) in the data and at least two deals in the year. In both cases, we observe a larger coefficient for non-professional investors (about 33 percent in column 1). The coefficient on professional investors is itself large in magnitude (22 percent) but is not statistically significant. The coefficients are not statistically different from one another. For this reason, as well as the somewhat arbitrary definition of "professional", this evidence is only suggestive. However, taken together with the rest of the results, it suggests that the tax credit programs did not motivate additional seed investment in potentially high-growth startups, implying that tax arbitrage and rent seeking considerations were likely at the core of the response to the policy.

\subsection{Where are the constrained firms?}

The second remaining puzzle is why constrained startups fail to select into the tax credit programs. As mentioned in Section 4.1.1, we observe the same null effects in state-years that run out of money and in those that do not run out of money. In the latter case, constrained startups could not have been "left out."

One explanation for the lack of "constrained startups" is provided by Gonzalez-Uribe \& Paravisini (2019). They find low take-up in a UK angel subsidy program, where insiders are explicitly excluded. They argue that the high cost of adding new external investors, which emerges from asymmetric information or governance frictions, explains the low take-up. This high cost could explain why, in our context, constrained firms do not use the credit, while 
those that do seem to have deals that would have been likely to happen anyway.

This explanation could be reinforced by the presence of informational frictions. True startups that are financially constrained may often be unaware of the programs because their managers are younger, less sophisticated about government policy, or have spent less time in the state. The types of investors interested in potentially high-growth startups may also not know about the programs, especially if they are not local. ${ }^{45}$ True angel investors may also find the administrative burdens of a tax credit too cumbersome. Paradoxically, cost considerations could be more important for professional angels. In selecting investments, they may focus on the "fat tails" of the startup outcome distribution. If the investment is very successful (e.g., culminates in an IPO), the marginal value of the tax credit may be perceived as second order relative to the ex-ante administrative costs.

A second mechanism that could reinforce the initial difference in the cost of accessing the tax credit is the presence of coordination frictions: Taking advantage of the tax credit may require the company to already have established connections with the investor. The programs typically require both parties to register in advance of the deal, often at a particular time of year. In this context, the prevalence of insider investors is consistent with needing to have established the investment in advance. Coordination costs could be high for professional investors, especially to the degree that they view angel investments as call options on the small chance that the startup becomes a home run. To the degree angel investing has this binary character, even a large marginal incentive may not affect decision-making, particularly in the presence of administrative and coordination costs. Information and coordination frictions may both be at play, and our data do not permit us to distinguish between them.

Two pieces of descriptive evidence are consistent with these frictions. First, a disproportionate share of tax credit recipient investors is located in the state. Table 3 shows that 80 percent of investors are located in-state, which seems much higher than would be the case if the beneficiary companies were targeting a random sample of U.S. angel investors. For example, 90 percent of investors who receive tax credits in New Mexico are in-state, but according to Huang et al. (2017), only 3.8 percent of all U.S. angel investors are in the entire Southwest region, which encompasses five states. Second, social

\footnotetext{
${ }^{45}$ Note most programs allow out of state investors to receive cash in lieu of income tax credits.
} 
ties seem to play a role in explaining selection into the programs. Pre-existing social ties could both mitigate coordination frictions and help information flow about the credits between firms and investors. To test for pre-existing social ties, we looked for attendance at the same university. Among the investors where we observe at least one university from which they graduated, we examined whether an executive who isn't related by last name attended the same university. For 22 percent of companies where we observe both investor and executive universities, at least one investor shared a university with an unrelated executive. ${ }^{46}$ They are dominated by out-of-state MBA degrees; for example, there are four Wharton instances, two Kellogg, and a variety of other top schools, including Stanford GSB, Columbia GSB, and Duke Fuqua. Of course, there is no obvious benchmark for how often it should be the case that an angel investor attended the same university as an executive.

\section{Conclusion}

A public subsidy for investors could help compensate for the information frictions that create financial constraints for potentially high-growth startups, frictions thought to be especially severe outside the major entrepreneurship hubs. Angel investor tax credits, relative to direct programs such as grants, have the attractive feature of being relatively market-based tools that do not require the government to identify which companies deserve subsidy. While statelevel subsidies could simply reallocate investment from one region to another, the subsidies could also be a means to directly address concerns that there may be insufficient angel investment, especially outside of hub cities.

In this paper, we look for evidence that angel investor tax credits positively affect entrepreneurial activity. At the state level, we find some evidence that the programs had a positive impact on angels' activity in the state, but no evidence that this also translated into more employment growth in the area. Firm-level analyses confirm this result. We interpret these results as emerging from program design: the programs are taken up by

\footnotetext{
${ }^{46}$ This is 27 out of 122 companies. At the investor level, the rate is of course lower: out of 675 investors in these companies there are 35 cases for which we observe an executive who attended the same university.
} 
firms that do not appear to use the subsidy for real investment. As a result, the credits often appear to go towards tax arbitrage and have a limited real impact on the economy.

To provide evidence in line with this mechanism, we document three characteristics of the data. First, 37 percent of companies have previous outside equity, therefore suggesting that a large share of the affected firms are not really companies that are completely unable to raise external funding. Second, just 27 percent of beneficiary companies are in the highgrowth IT/Web/Computer sector, which disproportionately receives VC and generates highgrowth, innovative companies. This fact again suggests that the tax credit is not really used by industries where financing frictions are larger. Third, many beneficiary companies have insider investment, which eliminates the information asymmetry that might cause financial constraints. When we put these three channels together, we find that just 9.5 percent of beneficiary companies have no insider investment, are in the IT/Web/Computer sector, and also did not previously raise external equity.

It seems likely that the tax credit program implementation could be improved to align more closely with the stated goal of encouraging high-growth, innovative entrepreneurial activity. We cannot assess how investor tax credits might operate outside our context, but our findings are at a minimum relevant to U.S. state-level policymakers. We document that U.S. state-level angel investor tax credit programs have no discernible effect on local highgrowth entrepreneurship. The funding dedicated to these programs is small relative to total state budgets, but there are meaningful opportunity costs: the programs are typically a large share of state entrepreneurship funding and there are well-established positive effects of other policy tools. 


\section{References}

Acharya, V. V. \& Subramanian, K. V. (2009), 'Bankruptcy codes and innovation', The Review of Financial Studies 22(12), 4949-4988.

Acs, Z., Audretsch, D. \& Feldman, M. (1994), 'R\&D spillovers and recipient firm size', The Review of Economics and Statistics 76(2), 336-340.

Agrawal, A., Rosell, C. \& Simcoe, T. S. (2014), Do tax credits affect R\&D expenditures by small firms? Evidence from Canada, Technical report, National Bureau of Economic Research.

Akcigit, U., Baslandze, S. \& Stantcheva, S. (2016), 'Taxation and the international mobility of inventors', American Economic Review 106(10), 2930-81.

Angrist, J. D. \& Pischke, J.-S. (2008), Mostly harmless econometrics: An empiricist's companion, Princeton university press.

Appel, I., Farre-Mensa, J. \& Simintzi, E. (2017), Patent Trolls an Small Business Employmeny, Harvard Business School.

Balsmeier, B., Kurakina, M. \& Fleming, L. (2018), 'R\&D tax credits: Mechanisms of private and public value'. Working Paper.

Barnatchez, K., Crane, L. D. \& Decker, R. (2017), 'An assessment of the national establishment time series (nets) database'.

Baumol, W. J. (1990), 'Entrepreneurship: Productive, unproductive, and destructive', Journal of political economy 98(5, Part 1), 893-921.

Becker, B. (2015), 'Public r\&d policies and private r\&d investment: A survey of the empirical evidence', Journal of Economic Surveys 29(5), 917-942.

Bell, A., Chetty, R., Jaravel, X., Petkova, N. \& Van Reenen, J. (2018), 'Who becomes an inventor in america? the importance of exposure to innovation', The Quarterly Journal of Economics 134(2), 647-713.

Bernstein, S., Giroud, X. \& Townsend, R. R. (2016), 'The impact of venture capital monitoring', The Journal of Finance 71(4), 1591-1622.

Bernstein, S., Korteweg, A. \& Laws, K. (2017), 'Attracting early-stage investors: Evidence from a randomized field experiment', The Journal of Finance 72(2), 509-538.

Bernstein, S., Lerner, J. \& Mezzanotti, F. (2018), 'Private equity and financial fragility during the crisis', The Review of Financial Studies 32(4), 1309-1373.

Billings, A., Glazunov, S. \& Houston, M. (2001), 'The role of taxes in corporate research and development spending', RED Management 31(4), 465-477.

Bloom, N., Griffith, R. \& Van Reenen, J. (2002), 'Do r\&d tax credits work? evidence from a panel of countries 1979-1997', Journal of Public Economics 85(1), 1-31.

Bock, C. \& Watzinger, M. (2017), 'The capital gains tax: A curse but also a blessing for venture capital investment', Journal of Small Business Management . 
Bottero, M., Lenzu, S. \& Mezzanotti, F. (2015), 'Sovereign debt exposure and the bank lending channel: impact on credit supply and the real economy', Bank of Italy Temi di Discussione (Working Paper) No 1032.

Bronzini, R. \& Iachini, E. (2014), 'Are incentives for r\&d effective? evidence from a regression discontinuity approach', American Economic Journal: Economic Policy 6(4), 100-134.

Chen, H., Gompers, P., Kovner, A. \& Lerner, J. (2010), 'Buy local? the geography of venture capital', Journal of Urban Economics 67(1), 90-102.

Clausen, T. H. (2009), 'Do subsidies have positive impacts on R\&D and innovation activities at the firm level?', Structural Change and Economic Dynamics 20(4), 239-253.

Cullen, J. B. \& Gordon, R. H. (2007), 'Taxes and entrepreneurial risk-taking: Theory and evidence for the us', Journal of Public Economics 91(7-8), 1479-1505.

Curtis, E. M. \& Decker, R. (2018), 'Entrepreneurship and state taxation'.

Da Rin, M., Di Giacomo, M. \& Sembenelli, A. (2011), 'Entrepreneurship, firm entry, and the taxation of corporate income: Evidence from europe', Journal of public economics 95(910), 1048-1066.

Da Rin, M., Nicodano, G. \& Sembenelli, A. (2006), 'Public policy and the creation of active venture capital markets', Journal of Public Economics 90(8-9), 1699-1723.

Dechezleprêtre, A., Einiö, E., Martin, R., Nguyen, K.-T. \& Van Reenen, J. (2016), Do tax incentives for research increase firm innovation? An RD design for R\&D, Technical report, National Bureau of Economic Research.

Decker, R., Haltiwanger, J., Jarmin, R. \& Miranda, J. (2014), 'The role of entrepreneurship in us job creation and economic dynamism', The Journal of Economic Perspectives 28(3), 3-24.

Denes, M., Wang, X. \& Xu, T. (2019), 'Financing entrepreneurship: Tax incentives for early-stage investors', Available at SSRN 3454633 .

Dharmapala, D., Foley, C. F. \& Forbes, K. J. (2011), 'Watch what i do, not what i say: The unintended consequences of the homeland investment act', The Journal of Finance 66(3), 753787.

Drucker, S. \& Puri, M. (2008), 'On loan sales, loan contracting, and lending relationships', The Review of Financial Studies 22(7), 2835-2872.

Duchin, R., Ozbas, O. \& Sensoy, B. A. (2010), 'Costly external finance, corporate investment, and the subprime mortgage credit crisis', Journal of financial economics 97(3), 418-435.

Ewens, M. \& Townsend, R. (2018), 'Are early stage investors biased against women?', Journal of Financial Economics .

Foster, L., Haltiwanger, J. \& Syverson, C. (2008), 'Reallocation, firm turnover, and efficiency: Selection on productivity or profitability?', American Economic Review 98(1), 394-425.

Gennaioli, N., La Porta, R., Lopez-de Silanes, F. \& Shleifer, A. (2012), 'Human capital and regional development', The Quarterly journal of economics 128(1), 105-164. 
Gompers, P. A. \& Lerner, J. (1997), 'Venture capital and the creation of public companies: do venture capitalists really bring more than money?', The Journal of Private Equity pp. 15-32.

Gompers, P. A. \& Sahlman, W. (2001), 'Entrepreneurial finance: A casebook'.

Gompers, P. A. \& Wang, S. Q. (2017), 'Diversity in innovation', NBER Working Paper (23082).

Gonzalez-Uribe, J. \& Leatherbee, M. (2017), 'The effects of business accelerators on venture performance: Evidence from start-up chile', The Review of Financial Studies 31(4), 1566-1603.

Gonzalez-Uribe, J. \& Paravisini, D. (2019), 'How sensitive is young firm investment to the cost of outside equity? evidence from a uk tax relief'.

Gordon, R. H. (1998), 'Can high personal tax rates encourage entrepreneurial activity?', Staff Papers 45(1), 49-80.

Graham, J. R. (2003), 'Taxes and corporate finance: A review', The Review of Financial Studies 16(4), 1075-1129.

Griliches, Z. (1992), 'The search for R\&D spillovers', The Scandinavian Journal of Economics pp. S29-S47.

Hall, B. H. (1993), 'R\&D tax policy during the 1980s: Success or failure?', Tax policy and the economy $7,1-35$.

Hall, B. \& Van Reenen, J. (2000), 'How effective are fiscal incentives for R\&D? A review of the evidence', Research Policy 29(4), 449-469.

Haltiwanger, J., Jarmin, R. S. \& Miranda, J. (2013), 'Who creates jobs? small versus large versus young', Review of Economics and Statistics 95(2), 347-361.

Hombert, J. \& Matray, A. (2016), 'The real effects of lending relationships on innovative firms and inventor mobility', The Review of Financial Studies 30(7), 2413-2445.

Hoshi, T., Kashyap, A. \& Scharfstein, D. (1991), 'Corporate structure, liquidity, and investment: Evidence from japanese industrial groups', The Quarterly Journal of Economics 106(1), 33-60.

Howell, S. (Forthcoming), 'Reducing information frictions in venture capital: The role of new venture competitions', Journal of Financial Economics .

Howell, S. \& Brown, D. J. (2019), 'Do cash windfalls affect wages? Evidence from R\&D grants'.

Howell, S. T. (2017), 'Financing innovation: evidence from r\&d grants', American Economic Review 107(4), 1136-64.

Huang, L., Wu, A., Lee, M. J., Bao, J., Hudson, M. \& Bolle, E. (2017), 'The american angel'.

Hubbard, R. G. (1998), 'Capital-market imperfections and investment', Journal of Economic Literature 36(1), 193-225.

Jacob, M. \& Michaely, R. (2017), 'Taxation and dividend policy: the muting effect of agency issues and shareholder conflicts', The Review of Financial Studies 30(9), 3176-3222. 
Jeng, L. A. \& Wells, P. C. (2000), 'The determinants of venture capital funding: evidence across countries', Journal of corporate Finance 6(3), 241-289.

Jensen, M. C. \& Meckling, W. H. (1976), 'Theory of the firm: Managerial behavior, agency costs and ownership structure', Journal of financial economics 3(4), 305-360.

Kerr, W. R., Lerner, J. \& Schoar, A. (2011), 'The consequences of entrepreneurial finance: Evidence from angel financings', The Review of Financial Studies 27(1), 20-55.

Kerr, W. R. \& Nanda, R. (2011), '8 financing constraints and entrepreneurship', Handbook of Research on Innovation and Entrepreneurship p. 88.

Keuschnigg, C. \& Nielsen, S. B. (2002), 'Tax policy, venture capital, and entrepreneurship', Journal of Public economics 87(1), 175-203.

Klassen, K. J., Pittman, J. A., Reed, M. P. \& Fortin, S. (2004), 'A cross-national comparison of R\&D expenditure decisions: Tax incentives and financial constraints', Contemporary Accounting Research 21(3), 639-680.

Krishnan, K., Nandy, D. K. \& Puri, M. (2014), 'Does financing spur small business productivity? evidence from a natural experiment', The Review of Financial Studies 28(6), 1768-1809.

Lach, S. (2002), 'Do r\&d subsidies stimulate or displace private r\&d? evidence from israel', The journal of industrial economics 50(4), 369-390.

Landoni, M. (2018), 'Tax distortions and bond issue pricing', Journal of Financial Economics 129(2), 382-393.

Lerner, J. (2009), Boulevard of broken dreams: why public efforts to boost entrepreneurship and venture capital have failed-and what to do about it, Princeton University Press.

Lerner, J., Schoar, A., Sokolinski, S. \& Wilson, K. (2018), 'The globalization of angel investments: Evidence across countries', Journal of Financial Economics 127(1), 1-20.

Lindsey, L. \& Stein, L. C. (2019), 'Angels, entrepreneurship, and employment dynamics: Evidence from investor accreditation rules'.

Mamuneas, T. P. \& Nadiri, M. I. (1996), 'Public R\&D policies and cost behavior of the US manufacturing industries', Journal of Public Economics 63(1), 57-81.

McCutchen, W. W. (1993), 'Estimating the impact of the R\&D tax credit on strategic groups in the pharmaceutical industry', Research Policy 22(4), 337-351.

McDonald, R. L. (2001), 'Cross-border investing with tax arbitrage: The case of german dividend tax credits', The Review of Financial Studies 14(3), 617-657.

McKenzie, D. (2017), 'Identifying and spurring high-growth entrepreneurship: experimental evidence from a business plan competition', American Economic Review 107(8), 2278-2307.

Moretti, E. \& Wilson, D. J. (2017), 'The effect of state taxes on the geographical location of top earners: Evidence from star scientists', American Economic Review 107(7), 1858-1903. 
Mukherjee, A., Singh, M. \& Žaldokas, A. (2017), 'Do corporate taxes hinder innovation?', Journal of Financial Economics 124(1), 195-221.

Myers, S. C. \& Majluf, N. S. (1984), 'Corporate financing and investment decisions when firms have information that investors do not have', Journal of financial economics 13(2), 187-221.

Poterba, J. M. (1989), 'Venture capital and capital gains taxation', Tax policy and the economy 3, 47-67.

Schoar, A. (2010), 'The divide between subsistence and transformational entrepreneurship', Innovation policy and the economy 10(1), 57-81.

Serrato, J. C. S. \& Zidar, O. (2018), 'The structure of state corporate taxation and its impact on state tax revenues and economic activity', Journal of Public Economics 167, 158-176.

Slemrod, J. \& Yitzhaki, S. (2002), Tax avoidance, evasion, and administration, in 'Handbook of public economics', Vol. 3, Elsevier, pp. 1423-1470.

Stiglitz, J. E. \& Weiss, A. (1981), 'Credit rationing in markets with imperfect information', The American economic review 71(3), 393-410.

Wilson, D. J. (2009), 'Beggar thy neighbor? the in-state, out-of-state, and aggregate effects of r\&d tax credits', The Review of Economics and Statistics 91(2), 431-436.

Yagan, D. (2015), 'Capital tax reform and the real economy: The effects of the 2003 dividend tax cut', American Economic Review 105(12), 3531-63.

Zwick, E. \& Mahon, J. (2017), 'Tax policy and heterogeneous investment behavior', American Economic Review 107(1), 217-48. 
Figure 1: Total Expenditure on Angel Investor Tax Credit Programs

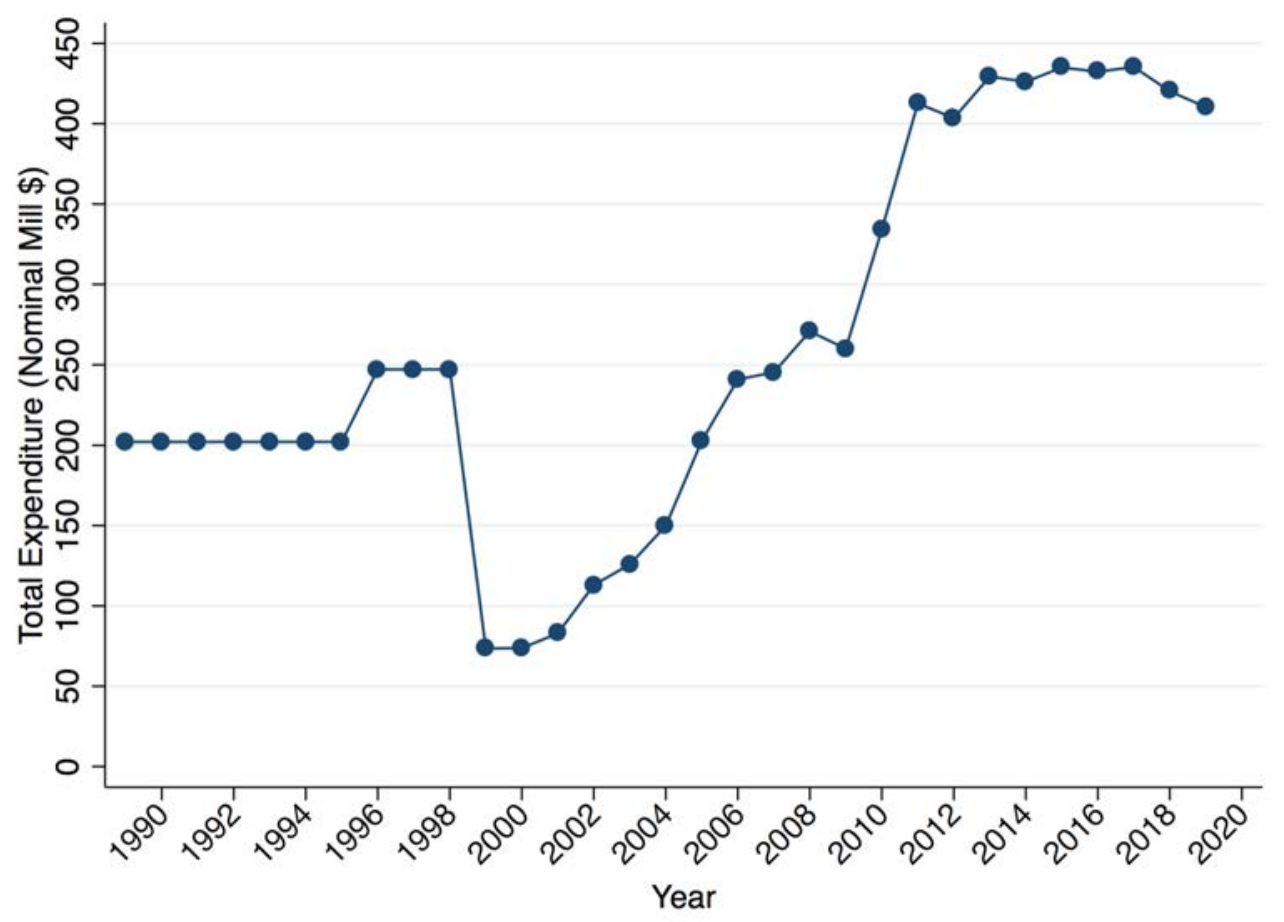

Note: This figure shows the total annual expenditure on state angel investor tax credits (i.e. takeup). All states in Table 1 are included except Oklahoma and New York, for which no data are available. The total across all years is $\$ 8.13$ billion. On average, take-up is 88 percent of allocated funding. 
Figure 2: Angel Investor Tax Credit Program Effect by Year Around Implementation
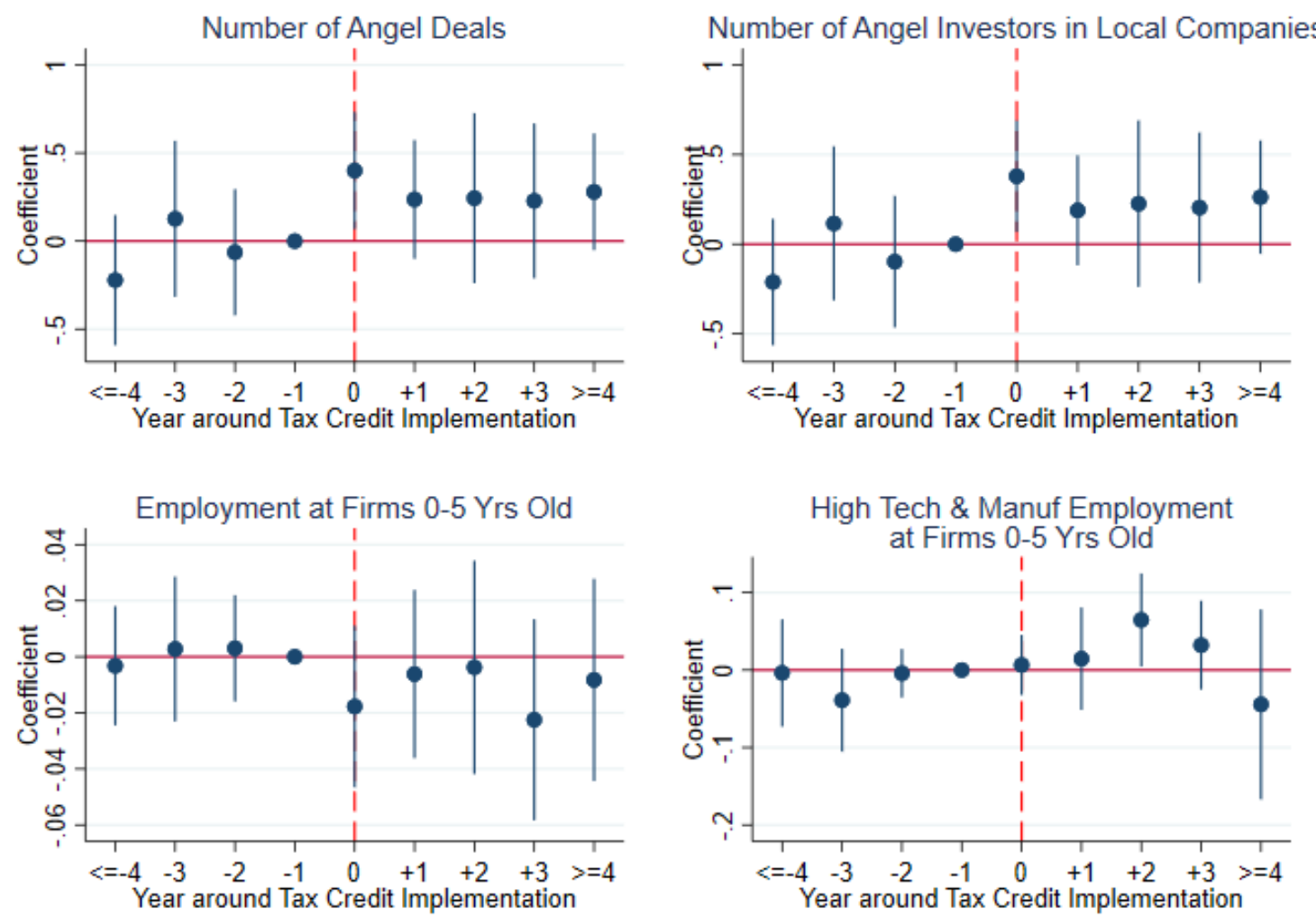

Note: This figure shows the annual effect of introducing an angel tax credit on key investment and employment outcomes using a year-by-year version of the difference-in-differences design. Otherwise the specification is the same as in Equation 1. The year before policy introduction is normalized to zero. Standard errors are clustered at state-level. 95\% confidence intervals are shown. 
Figure 3: Multiple Models and Placebo Tests for the Effect of Angel Investor Tax Credit Programs
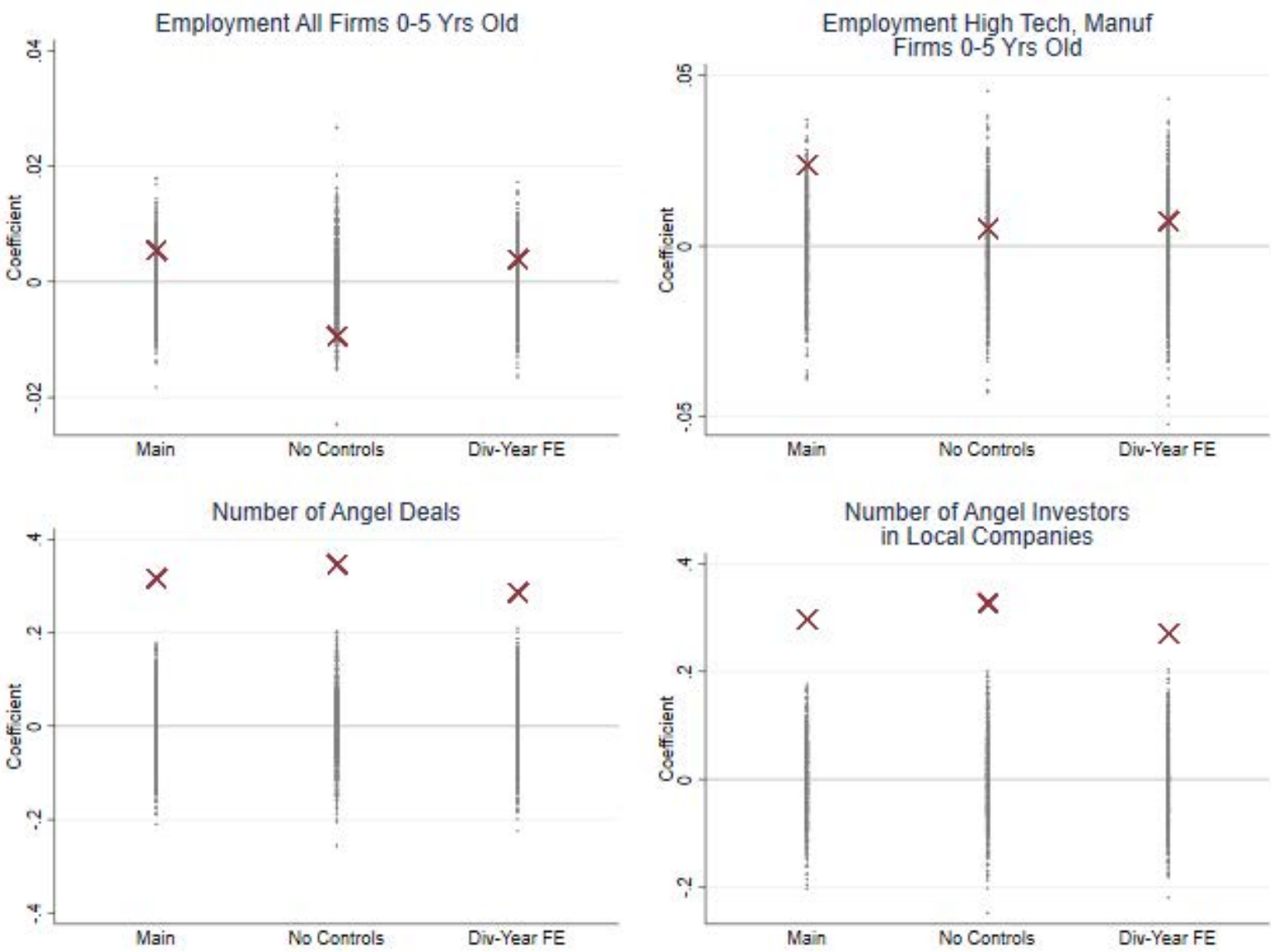

Placebo Tests

\section{$X$ Estimated Coefficient}

Note: This figure shows the three models for estimating the effect of introducing an angel tax credit on key employment and investment outcomes. The specification in "Main" is the same as in Equation 1. We remove controls in the middle model, and add Census division by year fixed effects in the right-hand model. The estimated coefficient for the actual effect of the program introduction is denoted by a red "X" for each model. The black dots represent the estimated coefficient for 1000 placebo tests in which state-years are randomly assigned tax credits with the same overall distribution as the true assignment. 
Figure 4: Sector Distribution Comparison

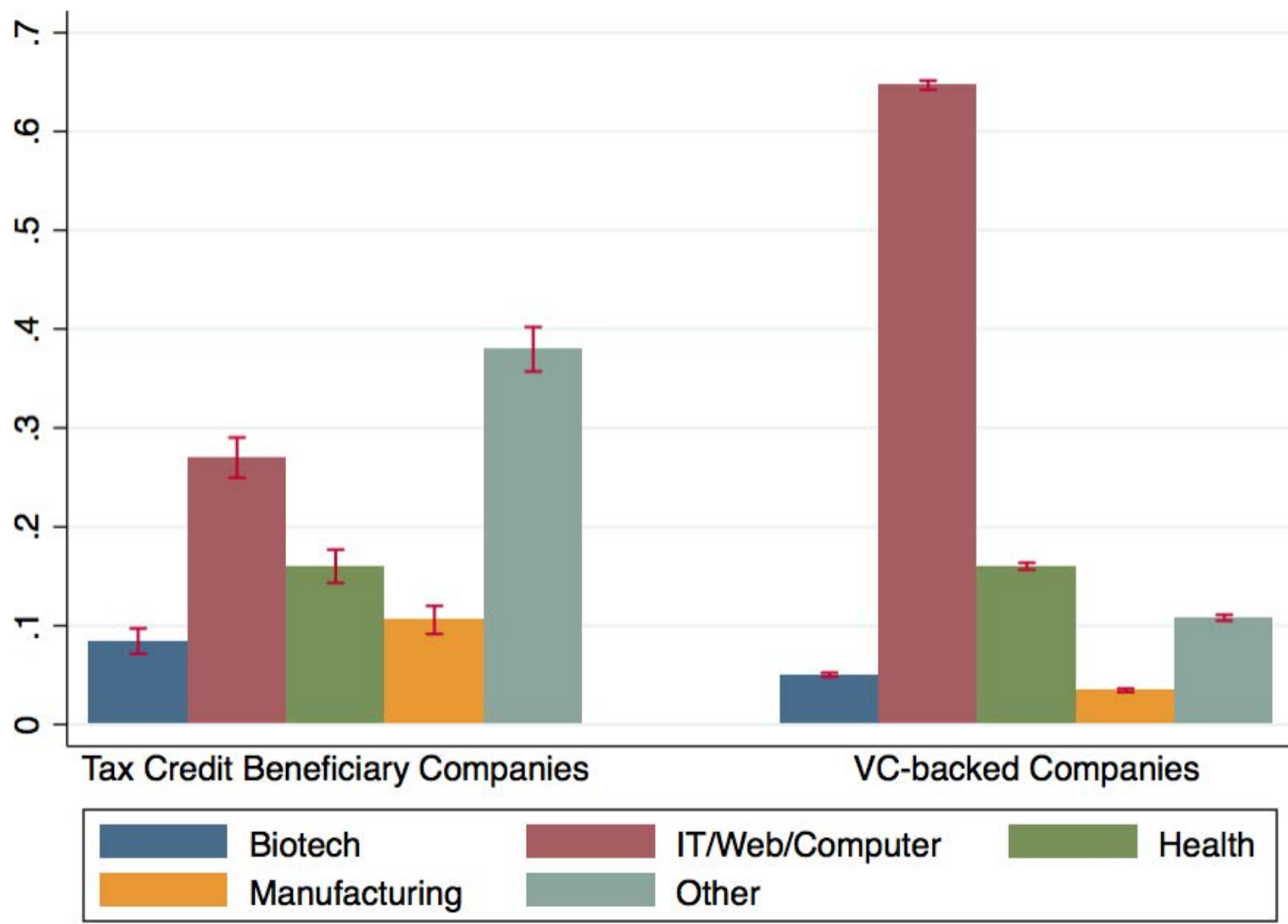

Note: This figure shows the sectoral distribution of venture capital-backed companies and tax credit beneficiary companies. There are 19,229 venture-capital backed companies between 2005 and 2018 and 1,818 tax credit beneficiary companies between 2005 and 2018 . 
Table 1: State Tax Credit Program Summary (Details in Appendix)

\begin{tabular}{|c|c|c|c|c|c|c|c|c|c|}
\hline State & Program & $\begin{array}{l}\text { Effective } \\
\text { Year }\end{array}$ & $\begin{array}{l}\text { Expiration } \\
\text { Year }\end{array}$ & $\begin{array}{c}\text { Share of } \\
\text { Investment } \\
\text { (Inv) to } \\
\text { Claim as TC }\end{array}$ & $\begin{array}{l}\text { Allocated } \\
\text { State } \\
\text { Funding } \\
(\mathrm{Sm} / \mathrm{yr})\end{array}$ & $\begin{array}{l}\text { Total Angel } \\
\text { Inv in State } \\
\text { During Eff. } \\
\text { Year (Smill) }\end{array}$ & $\begin{array}{c}\text { State } \\
\text { Funding as } \\
\text { Share of } \\
\text { Total Angel } \\
\text { Inv in State }\end{array}$ & $\left|\begin{array}{c}\text { Individuals or } \\
\text { Groups } \\
\text { Qualify for } \\
\text { Tax Credit } \\
\text { (TC) }\end{array}\right|$ & \begin{tabular}{|l} 
\\
'First Come \\
First' Policy \\
\end{tabular} \\
\hline & & (1) & (2) & (3) & (4) & (5) & (6) & (7) & (8) \\
\hline Arkansas & Equity Investment Incentive Program & 2007 & 2019 & 0.333 & 6.25 & 0.00 & $\geq 1$ & Both & \\
\hline Arizona & Angel Investment Program & 2006 & 2021 & $0.3-0.35$ & 2.50 & 4.20 & 0.60 & Both & $\mathrm{Y}$ \\
\hline \multirow{2}{*}{ Colorado } & a. Innovation Investment Tax Credit & 2010 & 2010 & 0.15 & 0.75 & 44.62 & 0.02 & Both & $\mathrm{Y}$ \\
\hline & b. Advanced Industry Investment Tax Credit & 2014 & 2022 & $0.25-0.3$ & 0.75 & 143.59 & 0.01 & Both & $\mathrm{Y}$ \\
\hline Connecticut & Angel Investor Tax Credit Program & 2010 & 2019 & 0.25 & 3.00 & 33.04 & 0.09 & Both & $\mathrm{Y}$ \\
\hline Georgia & Qualified Investor Tax Credit & 2011 & 2018 & 0.35 & 10.00 & 28.97 & 0.35 & Individuals & $\mathrm{N}$ \\
\hline Hawaii & High Technology Business Investment Tax Credit & 1999 & 2010 & $0.1-1.0$ & & 12.41 & & Both & \\
\hline Illinois & Angel Investment Tax Credit Program & 2011 & 2021 & 0.25 & 10.00 & 49.87 & 0.20 & Both & $\mathrm{Y}$ \\
\hline Indiana & Venture Capital Investment Tax Credit Program & 2004 & 2020 & $0.2-0.25$ & 12.50 & 0.00 & $\geq 1$ & Both & $\mathrm{N}$ \\
\hline \multirow{2}{*}{ Iowa } & a. Innovation Fund Tax Credit & 2002 & 2008 & 0.2 & 10.00 & 0.00 & $\geq 1$ & Both & \\
\hline & b. Innovation Fund Tax Credit & 2012 & indef. & $0.2-0.25$ & 2.00 & 8.33 & 0.24 & Both & $\mathrm{Y}$ \\
\hline Kansas & Angel Investor Tax Credit & 2005 & 2022 & 0.5 & 6.00 & 0.00 & $\geq 1$ & Both & $\mathrm{Y}$ \\
\hline Kentucky & Angel Investment Act Tax Credit & 2015 & indef. & $0.4-0.5$ & 3.00 & 9.55 & 0.31 & Individuals & $\mathrm{Y}$ \\
\hline \multirow{2}{*}{ Louisiana } & a. Angel Investor Tax Credit & 2005 & 2009 & 0.252 & 3.60 & 1.50 & 2.40 & Individuals & $\mathrm{Y}$ \\
\hline & b. Angel Investor Tax Credit & 2011 & 2021 & 0.252 & 3.60 & 6.51 & 0.55 & Individuals & $\mathrm{Y}$ \\
\hline \multirow{2}{*}{ Maine } & a. Seed Capital Tax Credit Program & 1989 & 2012 & $0.4-0.6$ & 5.00 & 0.00 & $\geq 1$ & Both & $\mathrm{Y}$ \\
\hline & b. Seed Capital Tax Credit Program & 2014 & indef. & $0.4-0.6$ & 5.00 & 3.07 & 1.63 & Both & $\mathrm{Y}$ \\
\hline Maryland & Biotechnology Investment Incentive Tax Credit & 2007 & indef. & 0.5 & 12.00 & 75.32 & 0.16 & Both & $\mathrm{Y}$ \\
\hline Michigan & Small Business Investment Tax Credit & 2011 & 2011 & 0.25 & 9.00 & 24.81 & 0.36 & Groups & \\
\hline Minnesota & Angel Tax Credit & 2010 & 2017 & 0.25 & 15.00 & 33.70 & 0.45 & Individuals & \\
\hline Nebraska & Angel Investment Tax Credit & 2011 & 2022 & 0.4 & 4.00 & 13.27 & 0.30 & Both & $\mathrm{Y}$ \\
\hline New Jersey & Angel Investor Tax Credit Program & 2013 & indef. & 0.1 & 25.00 & 46.17 & 0.54 & Both & $\mathrm{Y}$ \\
\hline New Mexico & Angel Investment Credit & 2008 & 2025 & 0.25 & 2.00 & 7.20 & 0.28 & Both & $\mathrm{Y}$ \\
\hline New York & $\begin{array}{l}\text { Qualified Emerging Technology Company Tax } \\
\text { Credits }\end{array}$ & 2000 & indef. & $0.1-0.2$ & & 279.57 & & Both & \\
\hline North Carolin & Qualified Business Tax Credit Program & 2008 & 2013 & 0.25 & 7.50 & 15.82 & 0.47 & Both & $\mathrm{N}$ \\
\hline North Dakota & Seed Capital Investment Tax Credit & 2002 & indef. & 0.45 & 3.50 & 0.00 & $\geq 1$ & Both & $\mathrm{Y}$ \\
\hline \multirow{2}{*}{ Ohio } & a. Ohio Technology Investment Tax Credit & 1996 & indef. & $0.25-0.3$ & 45.00 & 0.00 & $\geq 1$ & Both & $\mathrm{Y}$ \\
\hline & b. InvestOhio & 2011 & indef. & $0.1-0.3$ & 50.00 & 46.66 & 1.07 & Both & $\mathrm{Y}$ \\
\hline Oklahoma & $\begin{array}{l}\text { Credit for Qualified Investment in Qualified Small } \\
\text { Business Capital Companies }\end{array}$ & 1998 & 2011 & 0.2 & & 0.00 & & Both & \\
\hline Rhode Island & Innovation Tax Credit & 2007 & 2016 & 0.5 & 0.50 & 6.18 & 0.08 & & \\
\hline South Carolin & High Growth Small Business Job Creation Act & 2013 & indef. & 0.35 & 5.00 & 11.20 & 0.45 & Individuals & \\
\hline Tennessee & Angel Tax Credit & 2017 & indef. & $0.33-0.5$ & 4.00 & 34.68 & 0.12 & Individuals & $\mathrm{Y}$ \\
\hline Virginia & $\begin{array}{l}\text { Qualified Equity and Subordinated Debt Investments } \\
\text { Credit }\end{array}$ & 1999 & indef. & 0.5 & 5.00 & 35.00 & 0.14 & Both & $\mathrm{N}$ \\
\hline West Virginia & High-Growth Business Investment Tax Credit & 2005 & 2008 & 0.5 & 1.00 & 0.00 & $\geq 1$ & Both & $\mathrm{Y}$ \\
\hline Wisconsin & Qualified New Business Venture Program & 2005 & indef. & 0.5 & 30.00 & 1.08 & 37.96 & Both & \\
\hline
\end{tabular}

Note: This table contains information on U.S. state angel tax credit programs. Additional details are in Appendix Table A.1. 
Table 2: Tax Credit Applicant Summary Statistics

\begin{tabular}{|c|c|c|}
\hline \multicolumn{3}{|c|}{ Panel 1: Unique Tax Credit Applicants by State } \\
\hline & Received Tax Credit & No Tax Credit \\
\hline $\mathrm{AZ}$ & 144 & 145 \\
\hline $\mathrm{CO}$ & 109 & 25 \\
\hline CT & 100 & 70 \\
\hline KS & 199 & 63 \\
\hline KY & 60 & 101 \\
\hline MD & 87 & \\
\hline MN & 338 & 205 \\
\hline NJ & 69 & 6 \\
\hline NM & 72 & \\
\hline $\mathrm{OH}$ & 374 & 537 \\
\hline $\mathrm{SC}$ & 65 & 136 \\
\hline WI & 206 & 116 \\
\hline Total & 1823 & 1404 \\
\hline
\end{tabular}

Panel 2: Summary Statistics

\begin{tabular}{|c|c|c|c|}
\hline & Received Tax Credit & No Tax Credit & T-Test p-value \\
\hline Tax Credit (TC) Amount ( $\$$ thou) & $\begin{array}{l}\text { Mean } \\
32\end{array}$ & $\begin{array}{c}\text { Mean } \\
0\end{array}$ & $\begin{array}{c}\mathrm{P} \text {-value } \\
0.00\end{array}$ \\
\hline $\begin{array}{l}\text { Any Financing Pre-TC } \\
\text { Amt Financing Pre-TC }(\$ \text { mill }) \\
\text { Any Financing 2yrs Post-TC } \\
\text { Amt Financing 2yrs Post-TC (\$ mill) } \\
\text { Startup Exited }\end{array}$ & $\begin{array}{l}.37 \\
3.7 \\
.26 \\
2.9 \\
.066\end{array}$ & $\begin{array}{l}.12 \\
1.9 \\
.16 \\
2 \\
.037\end{array}$ & $\begin{array}{l}0.00 \\
0.02 \\
0.00 \\
0.19 \\
0.00\end{array}$ \\
\hline $\begin{array}{l}\text { Emp in Credit Yr } \\
\text { Emp 2yrs Post-TC } \\
\text { Emp > p75 in Credit Yr } \\
\text { Emp > p75 2yrs Post-TC } \\
\text { Emp >10 in Credit Yr } \\
\text { Emp >10 2yrs Post-TC } \\
\text { Emp > }>25 \text { in Credit Yr } \\
\text { Emp > 25 2yrs Post-TC }\end{array}$ & $\begin{array}{l}6.5 \\
7.2 \\
.21 \\
.25 \\
.14 \\
.18 \\
.042 \\
.055\end{array}$ & $\begin{array}{l}6.2 \\
6.6 \\
.2 \\
.16 \\
.087 \\
.12 \\
.013 \\
.03\end{array}$ & $\begin{array}{l}0.85 \\
0.79 \\
0.68 \\
0.03 \\
0.04 \\
0.11 \\
0.04 \\
0.25\end{array}$ \\
\hline $\begin{array}{l}\text { Biotech } \\
\text { IT/Web/Computer } \\
\text { Goods and Services } \\
\text { Energy Tech } \\
\text { Financial } \\
\text { Health } \\
\text { Manufacturing } \\
\text { Other } \\
\end{array}$ & $\begin{array}{l}.084 \\
.27 \\
.12 \\
.043 \\
.016 \\
.16 \\
.11 \\
.2\end{array}$ & $\begin{array}{l}.059 \\
.2 \\
.15 \\
.029 \\
.03 \\
.092 \\
.11 \\
.33 \\
\end{array}$ & $\begin{array}{l}0.01 \\
0.00 \\
0.01 \\
0.04 \\
0.01 \\
0.00 \\
0.97 \\
0.00\end{array}$ \\
\hline
\end{tabular}

Note: This table contains summary statistics about companies that applied to be eligible for an investor tax credit, some of which did have an investor receive a credit and some of which did not. Panel 1 shows these two groups by state. Panel 2 compares characteristics. "Pre-TC" means before the application year. 
Table 3: Angel Investor Information

\begin{tabular}{|c|c|c|c|c|c|}
\hline \multicolumn{6}{|c|}{ Panel 1: Categorical Variables } \\
\hline & $\mathrm{N}$ & Fraction & & $\mathrm{N}$ & Fraction \\
\hline \multirow[t]{2}{*}{ Number of investor-tax credit pairs } & 8,218 & & Profession & 3,286 & \\
\hline & & & Corp. Exec. & & 0.82 \\
\hline Number of unique investors & 5,637 & & Doctor & & 0.073 \\
\hline Illinois & & 0.14 & Entrepreneur & & 0.062 \\
\hline Kentucky & & 0.05 & Lawyer & & 0.041 \\
\hline Maryland & & 0.16 & Investor & & 0.007 \\
\hline Minnesota & & 0.39 & Other & & 0.003 \\
\hline New Jersey & & 0.09 & & & \\
\hline New Mexico & & 0.03 & Race & 4,446 & \\
\hline \multirow[t]{2}{*}{ Ohio } & & 0.14 & White & & 0.95 \\
\hline & & & South Asian & & 0.03 \\
\hline \multirow[t]{2}{*}{ Location is in state } & 4,694 & 0.79 & East Asian & & 0.02 \\
\hline & & & Black & & 0.007 \\
\hline \multirow[t]{2}{*}{ Male } & 4,702 & 0.87 & Hispanic & & 0.002 \\
\hline & & & Middle Eastern & & 0.001 \\
\hline
\end{tabular}

Panel 2: Continuous Variables

\begin{tabular}{lcccccc} 
& $\mathrm{N}$ & Mean & Median & S.d. & Min & Max \\
\cline { 2 - 7 } Investment amount (\$thou) & 2,810 & 376 & 80 & 3,093 & 0.348 & 106,000 \\
Age & 2,363 & 41.9 & 42 & 13.1 & 18 & 77 \\
\hline \hline
\end{tabular}

Note: This table describes information gathered from LinkedIn about angel investors from four states that publicly release the names of angel investors. Corporate Executive is an investor who lists their current occupation as President, Vice President (SVP and VP), Partner, Principal, Managing Director, or Chief Officer other than CEO. An individuals's approximate age is derived from adding 22 years to the difference between the individual's college graduation year and the median year of investment of the sample, 2013. The number of observations $(\mathrm{N})$ indicates the sample for which the variable is available; for example, we observe the investor location (in LinkedIn data) for 4,694 unique investors. 
Table 4: Tax Credit Effect on Investment and Firms

Panel 1: Tax Credit Effect on Firms

\begin{tabular}{|c|c|c|c|c|}
\hline \multirow[t]{2}{*}{ Dependent variable: } & $\begin{array}{l}\text { Employment All } \\
\text { Firms 0-5 yrs Old }\end{array}$ & $\begin{array}{l}\text { Employment High Tech, } \\
\text { Manuf Firms 0-5 yrs Old }\end{array}$ & $\begin{array}{c}\text { Num Manuf } \\
\text { Firms 0-19 Emps }\end{array}$ & $\begin{array}{l}\text { Num High Tech } \\
\text { Firms 0-19 Emps }\end{array}$ \\
\hline & (1) & $(2)$ & (3) & (4) \\
\hline \multirow[t]{2}{*}{ Tax Credit } & 0.005 & 0.024 & -0.009 & -0.012 \\
\hline & {$[-0.02,0.03]$} & {$[-0.03,0.08]$} & {$[-0.03,0.01]$} & {$[-0.04,0.01]$} \\
\hline Observations & 725 & 725 & 686 & 686 \\
\hline$R^{2}$ & 0.821 & 0.675 & 0.708 & 0.871 \\
\hline State FE & Y & Y & Y & $\mathrm{Y}$ \\
\hline Year FE & Y & Y & Y & Y \\
\hline Controls & Y & Y & Y & Y \\
\hline
\end{tabular}

Panel 2: Tax Credit Effect on Investment

\begin{tabular}{|c|c|c|c|c|}
\hline \multirow[t]{2}{*}{ Dependent variable: } & $\begin{array}{l}\text { Num Angel } \\
\text { Deals }\end{array}$ & $\begin{array}{l}\text { Num Angel Investors } \\
\text { in Local Companies }\end{array}$ & $\begin{array}{l}\text { Num Angel Investors } \\
\text { from State }\end{array}$ & $\begin{array}{c}\text { Angel \& Seed } \\
\text { Amount }\end{array}$ \\
\hline & (1) & (2) & (3) & (4) \\
\hline \multirow[t]{2}{*}{ Tax Credit } & $0.205^{* *}$ & $0.298^{* *}$ & $0.186^{* *}$ & 0.092 \\
\hline & {$[0.02,0.4]$} & {$[0.04,0.6]$} & {$[0.04,0.3]$} & {$[-0.09,0.3]$} \\
\hline Observations & 735 & 735 & 735 & 441 \\
\hline$R^{2}$ & 0.642 & 0.613 & 0.739 & 0.298 \\
\hline State FE & $\mathrm{Y}$ & $\mathrm{Y}$ & Y & $\mathrm{Y}$ \\
\hline Year FE & $\mathrm{Y}$ & Y & $\mathrm{Y}$ & Y \\
\hline Controls & $\mathrm{Y}$ & Y & $\mathrm{Y}$ & Y \\
\hline
\end{tabular}

Panel 3: Tax Credit Effect on Investors by Type

\begin{tabular}{|c|c|c|c|c|}
\hline \multirow[t]{2}{*}{ Dependent variable: } & $\begin{array}{l}\text { Num Non-Prof } \\
\text { Investors (w Exit) }\end{array}$ & $\begin{array}{c}\text { Num Prof } \\
\text { Investors (w Exit) }\end{array}$ & $\begin{array}{l}\text { Num Non-Prof } \\
\text { Investors }\end{array}$ & $\begin{array}{c}\text { Num Prof } \\
\text { Investors }\end{array}$ \\
\hline & (1) & $(2)$ & $(3)$ & (4) \\
\hline \multirow{2}{*}{ Tax Credit } & $0.331^{* *}$ & 0.223 & $0.296^{* *}$ & 0.225 \\
\hline & {$[0.07,0.6]$} & {$[-0.04,0.5]$} & {$[0.04,0.6]$} & {$[-0.05,0.5]$} \\
\hline Observations & 735 & 735 & 735 & 735 \\
\hline$R^{2}$ & 0.611 & 0.499 & 0.549 & 0.506 \\
\hline State FE & $\mathrm{Y}$ & Y & $\mathrm{Y}$ & Y \\
\hline Year FE & $\mathrm{Y}$ & $\mathrm{Y}$ & Y & $\mathrm{Y}$ \\
\hline Controls & $\mathrm{Y}$ & $\mathrm{Y}$ & $\mathrm{Y}$ & $\mathrm{Y}$ \\
\hline
\end{tabular}

Note: This table contains estimates of the effect of the tax credit on firm and investment outcomes. In Panel 1, dependent variables are from the Census QWI and CBP. In Panel 2, number of deals and investors are from AngelList. Number of deals only includes a company's first financing on the AngelList platform. Angel Amount is from the financing data (CB Insights, Crunchbase). In Panel 3, investors in company state (from Panel 2 column 2) are assigned to be professonal or not. Professional investors in columns 1-2 are defined as having at least one exit in the data. In columns 3-4, they are defined as having at least one exit in the data and at least two deals in the year. 95 percent confidence intervals are in parentheses.

${ }^{*} p<0.10,{ }^{* *} p<0.05,{ }^{* * *} p<0.01$ 
Table 5: Angel Investors Serving as Executives or Manager at Company for which they Received Tax Credit

\begin{tabular}{|c|c|c|}
\hline & $\mathrm{N}$ & Fraction \\
\hline$\geq 1$ investor is executive or has family member who is executive & 628 & 0.35 \\
\hline Among Kentucky companies & 77 & 0.04 \\
\hline Among Maryland companies & 81 & 0.38 \\
\hline Among New Jersey companies & 63 & 0.24 \\
\hline Among New Mexico companies & 61 & 0.26 \\
\hline Among Ohio companies & 346 & 0.44 \\
\hline At least one investor is an executive & 628 & 0.33 \\
\hline
\end{tabular}

Panel 2: Investor-level statistics (unique tax credit recipient investors for which observe investor-company link)

Investor is executive or has family who is executive

\begin{tabular}{cc}
$\mathrm{N}$ & Fraction \\
\hline 3,560 & 0.14 \\
3,560 & 0.11
\end{tabular}

Note: This table describes information from the five states where we observe beneficiary companies linked to the investors who received tax credits for investing in them. Panel 1 reports information on the share of firms among the 628 unique tax credit beneficiary where investor is executive or has family member who is executive. Information on whether an investor is related to an executive is collected from SEC Form D filings, LinkedIn, and web research in cases where at least three investors share the same last name. The investor identifies as employed at the firm that recieved a tax credit and in which he/she invested for 294 unique investors, of which the investor is the $\mathrm{CEO} /$ founder. Panel 2 reports the same statistic in aggregate but using the data at investor-level, rather than firm-level. 
Table 6: Within-Program Financing and Exit Outcomes

Panel 1

Dependent Variable: Raised VC 2 Yrs Post-TC

\begin{tabular}{lccccc} 
& $(1)$ & $(2)$ & $(3)$ & $(4)$ & $(5)$ \\
\hline Got Tax Credit & $0.099^{* * *}$ & 0.015 & -0.0091 & -0.0068 & -0.0088 \\
& $(.022)$ & $\begin{array}{c}(.019) \\
(.018)\end{array}$ & $(.017)$ & $(.016)$ \\
Finance Pre-TC & & $0.33^{* * *}$ & $0.18^{* * *}$ & $0.18^{* * *}$ & $0.17^{* * *}$ \\
& & $(.032)$ & $(.026)$ & $(.027)$ & $(.028)$ \\
& & & & & \\
State-Year FE & No & No & No & Yes & Yes \\
Sector-Year FE & No & No & No & No & Yes \\
State FE & No & No & Yes & No & No \\
Sector FE & No & No & Yes & Yes & No \\
Year FE & No & No & Yes & No & No \\
& & & & & \\
Observations & 3227 & 3227 & 3227 & 3227 & 3227 \\
$R^{2}$ & 0.014 & 0.13 & 0.24 & 0.27 & 0.31 \\
\hline
\end{tabular}

Panel 2

\begin{tabular}{|c|c|c|c|c|c|}
\hline \multirow[t]{2}{*}{ Dependent Variable: } & \multicolumn{2}{|c|}{$\begin{array}{l}\text { Log amt raised } \\
2 \text { yrs Post-TC }\end{array}$} & \multirow{2}{*}{$\begin{array}{c}\text { Amt raised } \\
\text { 2yrs Post-TC } \\
(3)\end{array}$} & \multicolumn{2}{|c|}{ Exit } \\
\hline & & (2) & & & $(5)$ \\
\hline Got Tax Credit & $\begin{array}{c}1.66^{* * *} \\
(.31)\end{array}$ & $\begin{array}{l}0.047 \\
(.21)\end{array}$ & $\begin{array}{l}0.41 \\
(.28)\end{array}$ & $\begin{array}{c}0.029^{* * *} \\
(.0076)\end{array}$ & $\begin{array}{l}-0.0051 \\
(.0093)\end{array}$ \\
\hline Log amt raised before & & $\begin{array}{c}0.25^{* * *} \\
(.03)\end{array}$ & & & \\
\hline Amt raised before & & & $\begin{array}{l}0.13^{* *} \\
(.054)\end{array}$ & & \\
\hline Finance Pre-TC & & & & & $\begin{array}{c}0.086^{* * *} \\
(.015)\end{array}$ \\
\hline State-Year FE & No & Yes & No & No & Yes \\
\hline Sector-Year FE & No & Yes & Yes & No & Yes \\
\hline Observations & 2835 & 2835 & 2835 & 3227 & 3227 \\
\hline$R^{2}$ & 0.021 & 0.32 & 0.13 & 0.0040 & 0.11 \\
\hline
\end{tabular}

Note: This table shows estimates of the relationship between receiving a tax credit and financing outcomes. The dependent variable in Panel 1 is an indicator that denotes whether a startup received VC investment within two years after first applying to have an investor benefit from a tax credit. The dependent variables in Panel 2 are a continuous variable measuring the total amount of financing a startup receives within two years of its first credit year, log of that variable, and whether the startup exited, i.e. is acquired or has an IPO. In Panel 1, different columns report the results under different combinations of fixed-effects, going from no fixed-effects (column 1) to state-by-year and sector-by-year fixed-effects and control for previous financing in column 5. In Panel 2 we examine alternative outcomes, but report only the least restrictive (odd columns) and most restrictive (even columns) specifications. Standard errors are clustered at state-by-year level. 
Table 7: Within-Program Employment Outcomes

\begin{tabular}{|c|c|c|c|c|c|}
\hline \multirow{3}{*}{ Dependent Variable: } & \multicolumn{4}{|c|}{ Panel 1} & \\
\hline & \multicolumn{5}{|c|}{ Emp. $>25$ 2yrs Post-TC } \\
\hline & (1) & $(2)$ & (3) & (4) & $(5)$ \\
\hline Got Tax Credit & $0.011^{* * *}$ & -0.00054 & -0.00051 & -0.00011 & -0.00021 \\
\hline Emp $>25$ in Credit $\mathrm{Yr}$ & & $0.66^{* * *}$ & $\begin{array}{c}(.0024) \\
0.65^{* * *} \\
(.1)\end{array}$ & $\begin{array}{c}(.0025) \\
0.65^{* * *} \\
(.1)\end{array}$ & $\begin{array}{c}(.0020) \\
0.65^{* * *} \\
(.11)\end{array}$ \\
\hline Finance Pre-TC & & $\begin{array}{c}0.012^{* * *} \\
(.0035)\end{array}$ & $\begin{array}{c}0.014^{* * *} \\
(.0041)\end{array}$ & $\begin{array}{c}0.013^{* * *} \\
(.0041)\end{array}$ & $\begin{array}{c}0.015^{* * *} \\
(.0046)\end{array}$ \\
\hline State-Year FE & No & No & No & Yes & Yes \\
\hline Sector-Year FE & No & No & No & No & Yes \\
\hline Sector FE & No & No & Yes & Yes & No \\
\hline Year FE & No & No & Yes & No & No \\
\hline State FE & No & No & Yes & No & No \\
\hline Observations & 3227 & 3227 & 3227 & 3227 & 3227 \\
\hline$R^{2}$ & 0.0033 & 0.46 & 0.47 & 0.48 & 0.50 \\
\hline
\end{tabular}

Panel 2

\begin{tabular}{|c|c|c|c|c|c|c|}
\hline \multirow[t]{2}{*}{ Dependent Variable: } & \multicolumn{3}{|c|}{ Emp. $>10$ 2yrs Post-TC } & \multicolumn{3}{|c|}{ Emp. > p75 2yrs Post-TC } \\
\hline & (1) & $(2)$ & $(3)$ & (4) & $(5)$ & $(6)$ \\
\hline Got Tax Credit & $0.034^{* * *}$ & -0.0011 & 0.0023 & $0.047^{* * *}$ & 0.0052 & 0.011 \\
\hline Emp $>10$ in Credit Yr & & $\begin{array}{c}0.54^{* * *} \\
(.069)\end{array}$ & $\begin{array}{c}0.53^{* * * *} \\
(.07)\end{array}$ & & & \\
\hline Finance Pre-TC & & $0.038^{* * *}$ & $0.041^{* * *}$ & & $0.053^{* * *}$ & $0.053^{* * *}$ \\
\hline Emp $>$ p75 in Credit Yr & & & & & $\begin{array}{c}0.45^{* * *} \\
(.064)\end{array}$ & $\begin{array}{c}0.45^{* * *} \\
(.065)\end{array}$ \\
\hline State-Year FE & No & No & Yes & No & No & Yes \\
\hline Sector-Year FE & No & No & Yes & No & No & Yes \\
\hline Sector FE & No & Yes & No & No & Yes & No \\
\hline Year FE & No & Yes & No & No & Yes & No \\
\hline State FE & No & Yes & No & No & Yes & No \\
\hline Observations & 3227 & 3227 & 3227 & 3227 & 3227 & 3227 \\
\hline$R^{2}$ & 0.0094 & 0.39 & 0.46 & 0.014 & 0.36 & 0.41 \\
\hline
\end{tabular}

Note: This table shows estimates of the relationship between receiving a tax credit and employment outcomes. The dependent variable in Panel 1 is an indicator that denotes whether a startup received the 25 employees within two years after first applying to have an investor benefit from a tax credit. The dependent variable in Panel 2 are an indicator equal to one if a startup reached ten employees within two years of its first credit year (columns 1-3) and an indicator equal to one if a startup reached the top quartile of employment within two years of its first credit year (columns 4-6). In every specification, we control for the same measure as the outcome but measured in the year before the tax credit. In Panel 1, different columns report the results under different combinations of fixed-effects, going from no fixed-effects (column 1) to state-by-year and sector-by-year fixed-effects and control for previous financing in column 5. In Panel 2 we examine alternative outcomes, but reporting only the least restrictive (odd columns) and most restrictive (even columns) specifications. Standard errors are clustered at state-by-year level. 
Table 8: Different-State-Matched Employment and Exit Outcomes

\begin{tabular}{|c|c|c|c|c|}
\hline \multicolumn{5}{|c|}{ Panel 1: Employment } \\
\hline Dependent Variable: & \multicolumn{2}{|c|}{$\begin{array}{c}\text { Employment }>10 \\
2 \text { yrs Post-TC }\end{array}$} & \multicolumn{2}{|c|}{$\begin{array}{c}\text { Employment }>25 \\
2 \text { yrs Post-TC }\end{array}$} \\
\hline Got Tax Credit & $\begin{array}{c}(1) \\
0.0071 \\
(.017)\end{array}$ & $\begin{array}{c}(2) \\
-0.0012 \\
(.016)\end{array}$ & $\frac{(3)}{-0.0064}$ & $\begin{array}{c}(4) \\
-0.014 \\
(.0094)\end{array}$ \\
\hline $\begin{array}{l}\text { Sector-Year FE } \\
\text { Controls }\end{array}$ & $\begin{array}{l}\text { No } \\
\text { No }\end{array}$ & $\begin{array}{l}\text { Yes } \\
\text { Yes }\end{array}$ & $\begin{array}{l}\text { No } \\
\text { No }\end{array}$ & $\begin{array}{l}\text { Yes } \\
\text { Yes }\end{array}$ \\
\hline $\begin{array}{l}\text { Observations } \\
R^{2}\end{array}$ & $\begin{array}{l}2511 \\
0.50 \\
\end{array}$ & $\begin{array}{l}2511 \\
0.52 \\
\end{array}$ & $\begin{array}{l}2511 \\
0.44 \\
\end{array}$ & $\begin{array}{l}2511 \\
0.46 \\
\end{array}$ \\
\hline \multicolumn{5}{|c|}{ Panel 2: High Employment and Exits } \\
\hline Dependent Variable: & $\begin{array}{l}\text { Emplo } \\
2 \mathrm{yr}\end{array}$ & $\begin{array}{l}\text { nt }>\text { p75 } \\
\text { st-TC }\end{array}$ & Startı & Exit \\
\hline Got Tax Credit & $\begin{array}{c}(1) \\
0.024 \\
(.017)\end{array}$ & $\begin{array}{c}(2) \\
0.019 \\
(.015)\end{array}$ & 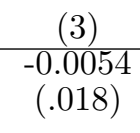 & $\begin{array}{c}(4) \\
-0.017 \\
(.015)\end{array}$ \\
\hline $\begin{array}{l}\text { Sector-Year FE } \\
\text { Controls }\end{array}$ & $\begin{array}{l}\text { No } \\
\text { No }\end{array}$ & $\begin{array}{l}\text { Yes } \\
\text { Yes }\end{array}$ & $\begin{array}{l}\text { No } \\
\text { No }\end{array}$ & $\begin{array}{l}\text { Yes } \\
\text { Yes }\end{array}$ \\
\hline $\begin{array}{l}\text { Observations } \\
R^{2}\end{array}$ & $\begin{array}{l}2511 \\
0.41 \\
\end{array}$ & $\begin{array}{l}2511 \\
0.44 \\
\end{array}$ & $\begin{array}{c}4115 \\
0.000031 \\
\end{array}$ & $\begin{array}{l}4115 \\
0.079\end{array}$ \\
\hline
\end{tabular}

Note: This table shows nearest-neighbor matching estimates. The dependent variables are defined within two years following the tax credit year, except for Exits (IPOs and acquisitions), which are ever after. In Panel 1, we consider as outcomes indicators that are equal to one if the employment is above ten workers (columns 1 and 2) or twenty-five workers (columns 3 and 4). In Panel 2, we consider as outcomes indicators that are equal to one if the employment is above the top quartile in the sample (columns 1 and 2) or if the firm experienced a succesful exit (columns 3 and 4). Mirroring the previous analyses, in odd columns we do not control for any fixed-effects, while in even columns we control for sector-by-year and the firm-level control discussed in the paper. Standard errors are clustered at state-by-year level. 


\section{Internet Appendix}

Online Appendix 1 
Table A.1: State Tax Credit Program Details (Continued from Table 1)

\begin{tabular}{|c|c|c|c|c|c|c|c|c|c|c|}
\hline State & & \begin{tabular}{|c|} 
TC Can \\
Exceed Total \\
State Income \\
Tax Owed \\
\end{tabular} & \begin{tabular}{|c|} 
Tax Credit \\
Can Be Sold \\
or \\
Transferred
\end{tabular} & $\begin{array}{c}\text { TC Can Be } \\
\text { Carried } \\
\text { Forward }\end{array}$ & $\begin{array}{l}\text { Number of Years of } \\
\text { Carry Forward }\end{array}$ & \begin{tabular}{|c|} 
Max TC \\
Amount Per \\
Business Per \\
Year (\$) \\
\end{tabular} & $\begin{array}{c}\text { Min Inv } \\
\text { Amount (\$) }\end{array}$ & \begin{tabular}{|c|} 
Registration \\
Requirement \\
(Req) for \\
Business
\end{tabular} & $\begin{array}{c}\text { Innovation } \\
\text { Req for } \\
\text { Business }\end{array}$ & Definition of Innovative \\
\hline & & (9) & (10) & (11) & (12) & (13) & (14) & (15) & (16) & \\
\hline AR & & $\mathrm{Y}$ & $\mathrm{Y}$ & $\mathrm{Y}$ & 9 & & & $\mathrm{Y}$ & $\mathrm{N}$ & \\
\hline $\mathbf{A Z}$ & & $\mathrm{Y}$ & $\mathrm{N}$ & $\mathrm{Y}$ & 3 & 600,000 & 25,000 & $\mathrm{Y}$ & $\mathrm{N}$ & \\
\hline \multirow{2}{*}{$\mathrm{CO}$} & a. & $\mathrm{Y}$ & $\mathrm{N}$ & $\mathrm{Y}$ & 5 & & 25,000 & $\mathrm{Y}$ & $\mathrm{N}$ & \\
\hline & $b$. & $\mathrm{Y}$ & $\mathrm{N}$ & $\mathrm{Y}$ & 5 & & 10,000 & $\mathrm{~N}$ & $\mathrm{~N}$ & \\
\hline CT & & $\mathrm{N}$ & $\mathrm{N}$ & $\mathrm{Y}$ & 5 & 500,000 & 25,000 & $\mathrm{Y}$ & $\mathrm{N}$ & \\
\hline GA & & $\mathrm{Y}$ & $\mathrm{N}$ & $\mathrm{Y}$ & 5 & & & $\mathrm{Y}$ & $\mathrm{N}$ & \\
\hline HI & & & & $\mathrm{Y}$ & Unlimited & & & & & \\
\hline IN & & $\mathrm{Y}$ & $\mathrm{Y}$ & $\mathrm{Y}$ & 5 & & & $\mathrm{Y}$ & $\mathrm{N}$ & \\
\hline \multirow{2}{*}{ IA } & a. & $\mathrm{Y}$ & $\mathrm{N}$ & $\mathrm{Y}$ & 5 & & & $\mathrm{~N}$ & & \\
\hline & $b$. & $\mathrm{Y}$ & $\mathrm{N}$ & $\mathrm{Y}$ & 3 & 500,000 & & $\mathrm{~N}$ & & \\
\hline KS & & $\mathrm{Y}$ & $\mathrm{Y}$ & $\mathrm{Y}$ & Unlimited & & & $\mathrm{N}$ & $\mathrm{Y}$ & $\begin{array}{l}\text { Exclusively owned tech, product or service } \\
\text { that is new. }\end{array}$ \\
\hline KY & . & $\mathrm{Y}$ & $\mathrm{Y}$ & $\mathrm{Y}$ & 15 & & 10,000 & $\mathrm{Y}$ & $\mathrm{N}$ & \\
\hline \multirow{2}{*}{ LA } & a. & & $\mathrm{Y}$ & & & & & $\mathrm{Y}$ & $\mathrm{N}$ & \\
\hline & $b$. & & $\mathrm{Y}$ & & & & & $\mathrm{Y}$ & $\mathrm{N}$ & \\
\hline \multirow{2}{*}{ ME } & a. & $\mathrm{Y}$ & & $\mathrm{Y}$ & 15 & $5,000,000$ & & $\mathrm{~N}$ & $\mathrm{~N}$ & \\
\hline & $b$. & $\mathrm{Y}$ & & $\mathrm{Y}$ & 15 & $5,000,000$ & & $\mathrm{~N}$ & $\mathrm{~N}$ & \\
\hline MI & & $\mathrm{Y}$ & & $\mathrm{Y}$ & 5 & $1,000,000$ & 20,000 & $\mathrm{Y}$ & $\mathrm{Y}$ & Has potential for high growth. \\
\hline MN & & & & $\mathrm{N}$ & & & 10,000 & $\mathrm{Y}$ & $\mathrm{Y}$ & Uses proprietary tech in a preferred industry \\
\hline NE & & & & $\mathrm{N}$ & & & 25,000 & $\mathrm{Y}$ & $\mathrm{Y}$ & Uses proprietary tech in a high-tech field. \\
\hline NJ & & & $\mathrm{N}$ & $\mathrm{N}$ & & & & $\mathrm{N}$ & $\mathrm{N}$ & \\
\hline NM & & $\mathrm{Y}$ & $\mathrm{N}$ & $\mathrm{Y}$ & $\begin{array}{l}5 \text { years if after } 2015 \\
3 \text { years if before } 2015\end{array}$ & & & $\mathrm{~N}$ & $\mathrm{~N}$ & \\
\hline NY & & $\mathrm{Y}$ & & $\mathrm{Y}$ & Unlimited & & & $\mathrm{N}$ & $\mathrm{Y}$ & $\begin{array}{l}\text { Produces emerging technologies or has } \\
\text { sufficient R\&D activities in NY. }\end{array}$ \\
\hline $\mathrm{NC}$ & & $\mathrm{Y}$ & $\mathrm{N}$ & $\mathrm{Y}$ & 5 & & & $\mathrm{Y}$ & $\mathrm{N}$ & \\
\hline ND & & $\mathrm{Y}$ & $\mathrm{N}$ & $\mathrm{Y}$ & 4 & 225,000 & & $\mathrm{Y}$ & $\mathrm{Y}$ & \\
\hline \multirow{2}{*}{ OH } & a. & $\mathrm{Y}$ & & $\mathrm{Y}$ & 15 & & & $\mathrm{Y}$ & $\mathrm{N}$ & \\
\hline & $b$. & $\mathrm{Y}$ & & $\mathrm{Y}$ & 15 & & & $\mathrm{Y}$ & $\mathrm{N}$ & \\
\hline OK & & $\mathrm{Y}$ & $\mathrm{N}$ & $\mathrm{Y}$ & $\begin{array}{c}3 \text { years if after } 2006 ; \\
10 \text { years if before } 2006\end{array}$ & & & $\mathrm{~N}$ & $\mathrm{~N}$ & \\
\hline RI & & $\mathrm{Y}$ & & $\mathrm{Y}$ & 3 & & & $\mathrm{Y}$ & $\mathrm{Y}$ & \\
\hline SC & & $\mathrm{Y}$ & $\mathrm{Y}$ & $\mathrm{Y}$ & 10 & & & $\mathrm{Y}$ & $\mathrm{N}$ & \\
\hline TN & & $\mathrm{Y}$ & $\mathrm{N}$ & $\mathrm{Y}$ & 5 & & 15,000 & $\mathrm{Y}$ & $\mathrm{Y}$ & $\begin{array}{l}\text { Has high-growth potential, SBIR or STTR } \\
\text { funding, or tech developed in TN. }\end{array}$ \\
\hline VA & & $\mathrm{Y}$ & & $\mathrm{Y}$ & 15 & & & $\mathrm{Y}$ & $\mathrm{N}$ & \\
\hline Wv & & $\mathrm{Y}$ & & $\mathrm{Y}$ & 4 & 500,000 & & $\mathrm{~N}$ & $\mathrm{~N}$ & \\
\hline WI & & $\mathrm{Y}$ & $\mathrm{N}$ & $\mathrm{Y}$ & 15 & $8,000,000$ & & $\mathrm{Y}$ & $\mathrm{Y}$ & \\
\hline
\end{tabular}

Online Appendix 2 


\begin{tabular}{|c|c|c|c|c|c|c|c|}
\hline State & & $\begin{array}{l}\text { Size Req for } \\
\text { Business }\end{array}$ & Note & $\begin{array}{l}\text { Age Req for } \\
\text { Business }\end{array}$ & Note & \begin{tabular}{|l} 
Industry Req \\
for Business
\end{tabular} & Note \\
\hline & & (17) & & (18) & & (19) & \\
\hline AR & & $\mathrm{N}$ & & $\mathrm{N}$ & & $\mathrm{Y}$ & $\begin{array}{l}\text { Adv materials and manufacturing; agriculture, food, and environmental; } \\
\text { biotech/eng, life sciences; IT; transportation }\end{array}$ \\
\hline $\mathbf{A Z}$ & & $\mathrm{Y}$ & $\begin{array}{l}\text { Assets }<\$ 10 \mathrm{~m} \text {. Assets }<\$ 2 \mathrm{~m} \text { if } \\
\text { before } 2012\end{array}$ & $\mathrm{~N}$ & & $\mathrm{~N}$ & \\
\hline \multirow{2}{*}{$\mathrm{CO}$} & a. & $\mathrm{Y}$ & $\begin{array}{l}\text { Annual revenue }<\$ 2 \mathrm{~m} \text {; assets }< \\
\$ 5 \mathrm{~m}\end{array}$ & $\mathrm{Y}$ & $<5$ years old & $\mathrm{Y}$ & R\&D or use of new tech, products, or processes \\
\hline & $b$. & $\mathrm{Y}$ & Annual revenue $<\$ 5 \mathrm{~m}$ & $\mathrm{Y}$ & $<5$ years old & $\mathrm{Y}$ & $\begin{array}{l}\text { Manufacturing; aerospace; bioscience; electronics; energy/natural } \\
\text { resources/cleantech; IT; infrastructure eng }\end{array}$ \\
\hline CT & & $\mathrm{Y}$ & $\begin{array}{l}<25 \text { full-time employees (FTEs); } \\
\text { annual gross revenue }<\$ 1 \mathrm{~m}\end{array}$ & $\mathrm{Y}$ & In $\mathrm{CT}<7$ years & $\mathrm{Y}$ & Bioscience; adv materials; photonics; IT; clean tech or other emerging tech \\
\hline GA & & $\mathrm{Y}$ & $\begin{array}{l}<20 \text { FTEs; annual revenue }< \\
\text { \$500k }\end{array}$ & $\mathrm{Y}$ & $<3$ years old & $\mathrm{Y}$ & $\begin{array}{l}\text { Manufacturing; processing; online / digital warehousing / wholesaling; } \\
\text { software; IT services; R\&D }\end{array}$ \\
\hline \multicolumn{8}{|r|}{ 空 } \\
\hline IL & & $\mathrm{Y}$ & $<100$ FTEs & $\mathrm{Y}$ & In IL $<10$ years & $\mathrm{Y}$ & $\begin{array}{l}\text { Manufacturing; bio/nanotech; communications; agricultural; clean energy } \\
\text { creation/storage; pharma; computer software or hardware; }\end{array}$ \\
\hline IN & & $\mathrm{Y}$ & Ave. annual revenues $<\$ 10 \mathrm{~m}$ & $\mathrm{~N}$ & & $\mathrm{Y}$ & Professional motor vehicle racing; $R \& D$; new tech \\
\hline \multirow{2}{*}{ IA } & a. & $\mathrm{Y}$ & Net worth $<\$ 3 \mathrm{~m}$ & $\mathrm{Y}$ & $<3$ years old & $\mathrm{Y}$ & Not primarily in retail, real estate, or health care \\
\hline & $b$. & $\mathrm{Y}$ & Net worth $<\$ 10 \mathrm{~m}$ & $\mathrm{Y}$ & $<6$ years old & $\mathrm{Y}$ & " " \\
\hline KS & & $\mathrm{Y}$ & Annual gross revenues $<\$ 5 \mathrm{~m}$ & $\mathrm{Y}$ & $<5$ years & $\mathrm{N}$ & \\
\hline KY & & $\mathrm{Y}$ & $\begin{array}{l}<100 \text { FTEs; net worth }<\$ 10 \mathrm{~m} ; \\
\text { income }<\$ 3 \mathrm{~m}\end{array}$ & $\mathrm{~N}$ & & $\mathrm{Y}$ & $\begin{array}{l}\text { Bioscience; environmental and energy tech; health and human dev; IT; } \\
\text { materials science and adv manufacturing }\end{array}$ \\
\hline \multirow{2}{*}{ LA } & a. & $\mathrm{Y}$ & $\begin{array}{l}<50 \text { FTEs; annual gross sales }< \\
\$ 10 \mathrm{~m} \text { or net worth }<\$ 2 \mathrm{~m}\end{array}$ & $\mathrm{~N}$ & & $\mathrm{~N}$ & \\
\hline & $b$. & $\mathrm{Y}$ & 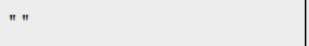 & $\mathrm{N}$ & & $\mathrm{N}$ & \\
\hline \multirow{2}{*}{ ME } & a. & $\mathrm{Y}$ & Annual gross sales $<\$ 3 \mathrm{~m}$ & $\mathrm{~N}$ & & $\mathrm{Y}$ & Manufacturing; adv tech; natural resources; visual media \\
\hline & $b$. & $\mathrm{Y}$ & Annual gross sales $<\$ 5 \mathrm{~m}$ & $\mathrm{~N}$ & & $\mathrm{Y}$ & $" n$ \\
\hline MD & & $\mathrm{Y}$ & $<50$ FTEs & $\mathrm{Y}$ & $<10$ years old & $\mathrm{Y}$ & Biotech \\
\hline MI & & $\mathrm{Y}$ & $\begin{array}{l}<100 \text { FTEs; pre-investment } \\
\text { valuation }<\$ 10 \mathrm{~m}\end{array}$ & $\mathrm{Y}$ & $\begin{array}{l}<5 \text { years old; }<10 \text { years if } \\
\text { business uses MI university }\end{array}$ & $\mathrm{Y}$ & $\begin{array}{l}\text { Adv materials; alt energy; defense and homeland security; IT; med tech; } \\
\text { next gen manufacturing }\end{array}$ \\
\hline $\mathbf{M N}$ & & $\mathrm{Y}$ & $<25$ FTEs & $\mathrm{Y}$ & $\begin{array}{l}<10 \text { years old; }<20 \text { if med tech } \\
\text { or pharma }\end{array}$ & $\mathrm{N}$ & $\begin{array}{l}\text { High-tech; agriculture; tourism; forestry; mining; manufacturing; } \\
\text { transportation }\end{array}$ \\
\hline NE & & $\mathrm{Y}$ & $<25$ FTEs & $\mathrm{N}$ & & $\mathrm{N}$ & \\
\hline NJ & & $\mathrm{Y}$ & $<225$ FTEs & $\mathrm{N}$ & & $\mathrm{Y}$ & $\begin{array}{l}\text { Adv computing; adv materials; biotech; electronics; IT; life sciences; med } \\
\text { tech; communications; renewable energy }\end{array}$ \\
\hline $\mathbf{N M}$ & & $\mathrm{Y}$ & $\begin{array}{l}<100 \text { FTEs; annual gross } \\
\text { revenues }<\$ 5 \mathrm{~m}\end{array}$ & $\mathrm{~N}$ & & $\mathrm{Y}$ & Manufacturing and high-tech \\
\hline NY & & $\mathrm{Y}$ & Annual sales $<\$ 10 \mathrm{~m}$ & $\mathrm{~N}$ & & $\mathrm{Y}$ & $\begin{array}{l}\text { Adv materials; engineering, production, and defense; electronics; IT; } \\
\text { biotech; remanufacturing }\end{array}$ \\
\hline NC & & $\mathrm{Y}$ & Annual gross revenue $<\$ 5 \mathrm{~m}$ & $\mathrm{~N}$ & & $\mathrm{Y}$ & Manufacturing; processing; warehousing; wholesaling; $R \& D$; services \\
\hline ND & & $\mathrm{N}$ & & $\mathrm{N}$ & & $\mathrm{N}$ & \\
\hline \multirow{2}{*}{ OH } & a. & $\mathrm{Y}$ & $\begin{array}{l}\text { Annual gross revenue }<\$ 2.5 \mathrm{~m} \text { or } \\
\text { net book value }<\$ 2.5 \mathrm{~m}\end{array}$ & $\mathrm{~N}$ & & $\mathrm{Y}$ & R\&D; biotech; IT; R\&D-derived tech \\
\hline & $b$. & $\mathrm{Y}$ & " " & $\mathrm{N}$ & & $\mathrm{Y}$ & " " \\
\hline OK & & $\mathrm{Y}$ & Net worth $<\$ 1 \mathrm{~m}$ & $\mathrm{~N}$ & & & \\
\hline RI & & $\mathrm{Y}$ & Annual gross revenues $<\$ 1 \mathrm{~m}$ & $\mathrm{~N}$ & & $\mathrm{Y}$ & $\begin{array}{l}\text { IT; digital media; healthcare; life science; marine trades; defense; financial, } \\
\text { professional and educational services; retail and design; industrial products }\end{array}$ \\
\hline SC & & $\mathrm{Y}$ & $<25$ FTEs; gross revenue $<\$ 2 \mathrm{~m}$ & $\mathrm{Y}$ & $<5$ years old & $\mathrm{Y}$ & Manufacturing, processing, warehousing, wholesaling; software; IT; R\&D \\
\hline TN & & $\mathrm{Y}$ & $<50$ FTEs; gross revenue $<\$ 3 \mathrm{~m}$ & $\mathrm{Y}$ & $<5$ years old & $\mathrm{N}$ & \\
\hline VA & & $\mathrm{Y}$ & Annual gross revenue $<\$ 3 \mathrm{~m}$ & $\mathrm{~N}$ & & $\mathrm{Y}$ & $\begin{array}{l}\text { Computing; adv materials; manufacturing; agriculture; biotech; electronics; } \\
\text { energy; environment; IT; med tech; nanotech }\end{array}$ \\
\hline WV & & $\mathrm{Y}$ & $\begin{array}{l}\text { Annual gross receipts }<\$ 20 \mathrm{~m} \text {; } \\
\text { payroll }<\$ 2.5 \mathrm{~m}\end{array}$ & $\mathrm{~N}$ & & $\mathrm{~N}$ & \\
\hline WI & & $\mathrm{Y}$ & $<100$ FTEs & $\mathrm{Y}$ & In $W I<10$ years & $\mathrm{Y}$ & $\begin{array}{l}\text { Manufacturing; biotech; med tech; software / hardware; semiconductors; } \\
\text { nanotech; communications; agriculture; clean energy }\end{array}$ \\
\hline
\end{tabular}




\begin{tabular}{|c|c|c|c|c|c|c|c|c|c|c|c|c|c|}
\hline State & & $\begin{array}{c}\text { Reporting } \\
\text { Req for } \\
\text { Investor's } \\
\text { Firm }\end{array}$ & $\begin{array}{l}\text { In-State } \\
\text { Location } \\
\text { Req for } \\
\text { Busines: }\end{array}$ & Note & \begin{tabular}{|c} 
Total \\
Previous \\
Inv Reg \\
for \\
Busines \\
\end{tabular} & Note & $\begin{array}{c}\text { Max TC } \\
\text { Amount Per } \\
\text { Investor Per } \\
\text { Year (\$) }\end{array}$ & \begin{tabular}{|c|} 
Max TC \\
Amount Per \\
Investor Per \\
Business Per \\
Year (\$) \\
\end{tabular} & \begin{tabular}{|c} 
Holding \\
or \\
Waiting \\
Req for \\
TC Claim
\end{tabular} & Note & \begin{tabular}{|c|} 
SEC \\
Accredita \\
tion Req \\
for \\
Investor \\
\end{tabular} & \begin{tabular}{|c|} 
Investor \\
Can Be \\
Employed \\
by \\
Business \\
\end{tabular} & $\begin{array}{c}\text { Investor } \\
\text { Can } \\
\text { Reside } \\
\text { Out-of- } \\
\text { State } \\
\end{array}$ \\
\hline & & $(20)$ & (21) & & (22) & & (23) & (24) & (25) & & (26) & (27) & (28) \\
\hline AR & & $\mathrm{N}$ & $\mathrm{N}$ & & $\mathrm{N}$ & & & & $\mathrm{N}$ & & $\mathrm{N}$ & $\mathrm{Y}$ & $\mathrm{Y}$ \\
\hline $\mathbf{A Z}$ & & $\mathrm{N}$ & $\mathrm{Y}$ & $\begin{array}{l}\text { Business and }>2 \text { full-time } \\
\text { employees (FTEs) }\end{array}$ & $\mathrm{Y}$ & $\begin{array}{l}<\$ 2 \mathrm{~m} \text { in total } \\
\text { inv }\end{array}$ & 250,000 & & $\mathrm{Y}$ & 1 year & $\mathrm{N}$ & $\mathrm{Y}$ & $\mathrm{Y}$ \\
\hline \multirow{2}{*}{$\mathrm{CO}$} & $a$. & $\mathrm{N}$ & $\mathrm{Y}$ & $\begin{array}{l}\text { Principal business, }>2 \text { FTEs, } \\
\text { and }>50 \% \text { of assets }\end{array}$ & $\mathrm{N}$ & & 20,000 & & $\mathrm{~N}$ & & $\mathrm{~N}$ & $\mathrm{Y}$ & \\
\hline & $b$. & $\mathrm{N}$ & $\mathrm{Y}$ & HQ and $>50 \%$ of FTEs & $\mathrm{Y}$ & $\begin{array}{l}<\$ 10 \mathrm{~m} \text { in inv, } \\
\text { debt, equity }\end{array}$ & 50,000 & & $\mathrm{~N}$ & & $\mathrm{~N}$ & & \\
\hline CT & & $\mathrm{N}$ & $\mathrm{Y}$ & $>75 \%$ of FTEs & $\mathrm{Y}$ & $\begin{array}{l}<\$ 2 \mathrm{~m} \text { in angel } \\
\text { financing }\end{array}$ & 250,000 & & \multicolumn{2}{|l|}{$\mathrm{N}$} & $\mathrm{Y}$ & $\mathrm{Y}$ & $\mathrm{Y}$ \\
\hline GA & & $\mathrm{N}$ & $\mathrm{Y}$ & HQ & $\mathrm{Y}$ & $\begin{array}{l}<\$ 1 \mathrm{~m} \text { in } \\
\text { equity or debt }\end{array}$ & 50,000 & & $\mathrm{Y}$ & 2 years & $\mathrm{Y}$ & $\mathrm{Y}$ & $\mathrm{Y}$ \\
\hline HI & & & & & & & 700,000 & & $\mathrm{Y}$ & 5 years & & & \\
\hline IL & & $\mathrm{Y}$ & $\mathrm{Y}$ & $\begin{array}{l}\text { Principal business and }>50 \% \\
\text { of FTEs }\end{array}$ & $\mathrm{Y}$ & $\begin{array}{l}<\$ 10 \mathrm{~m} \text { in } \mathrm{PE}, \\
<\$ 4 \mathrm{~m} \mathrm{TC} \text { inv }\end{array}$ & & 500,000 & $\mathrm{Y}$ & 3 years & $\mathrm{N}$ & $\mathrm{Y}$ & $\mathrm{Y}$ \\
\hline IN & & $\mathrm{N}$ & $\mathrm{Y}$ & $\begin{array}{l}\mathrm{HQ},>50 \% \text { of FTEs, and }> \\
75 \% \text { of assets }\end{array}$ & $\mathrm{N}$ & & $1,000,000$ & & & & $\mathrm{~N}$ & $\mathrm{Y}$ & $\mathrm{Y}$ \\
\hline \multirow[b]{2}{*}{ IA } & a. & $\mathrm{N}$ & $\mathrm{Y}$ & Principal business & $\mathrm{N}$ & & 100,000 & 50,000 & $\mathrm{Y}$ & 3 years & $\mathrm{N}$ & $\mathrm{Y}$ & $\mathrm{Y}$ \\
\hline & $b$. & $\mathrm{N}$ & $\mathrm{Y}$ & HQ and $>50 \%$ FTEs & $\mathrm{N}$ & & 100,000 & 50,000 & $\mathrm{Y}$ & $\begin{array}{l}\text { years if } \\
\text { before 2014, }\end{array}$ & $\mathrm{N}$ & $\mathrm{Y}$ & $\mathrm{Y}$ \\
\hline KS & & $\mathrm{Y}$ & $\mathrm{Y}$ & $\begin{array}{l}>60 \% \text { operations or }>80 \% \\
\text { production }\end{array}$ & \multicolumn{2}{|l|}{$\mathrm{N}$} & 250,000 & 50,000 & \multicolumn{2}{|r|}{ 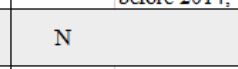 } & $\mathrm{Y}$ & $\mathrm{N}$ & $\mathrm{Y}$ \\
\hline $\mathbf{K Y}$ & & $\mathrm{Y}$ & $\mathrm{Y}$ & $\begin{array}{l}>50 \% \text { assets, operations, } \\
\text { and FTEs }\end{array}$ & $\mathrm{Y}$ & $\begin{array}{l}<\$ 1 \mathrm{~m} \text { in TC } \\
\text { angel inv }\end{array}$ & 200,000 & & & & $\mathrm{Y}$ & $\mathrm{N}$ & $\mathrm{Y}$ \\
\hline \multirow{2}{*}{ LA } & a. & $\mathrm{N}$ & $\mathrm{Y}$ & $\begin{array}{l}\text { Principal business and }>50 \% \\
\text { FTEs }\end{array}$ & $\mathrm{N}$ & & 362,880 & 181,440 & $\mathrm{Y}$ & 3 years & $\mathrm{Y}$ & $\mathrm{Y}$ & $\mathrm{Y}$ \\
\hline & $b$. & $\mathrm{N}$ & $\mathrm{Y}$ & $\begin{array}{l}\text { Principal business and }>50 \% \\
\text { FTEs }\end{array}$ & $\mathrm{N}$ & & 362,880 & 181,440 & $\mathrm{Y}$ & 3 years & $\mathrm{Y}$ & $\mathrm{Y}$ & $\mathrm{Y}$ \\
\hline \multirow{2}{*}{ ME } & a. & $\mathrm{Y}$ & $\mathrm{Y}$ & Physically reside in ME & $\mathrm{N}$ & & & 500,000 & & & $\mathrm{~N}$ & $\mathrm{Y}$ & \\
\hline & $b$. & $\mathrm{Y}$ & $\mathrm{Y}$ & Physically reside in ME & $\mathrm{N}$ & & & 500,000 & & & $\mathrm{~N}$ & $\mathrm{Y}$ & \\
\hline MD & & $\mathrm{N}$ & $\mathrm{Y}$ & $\mathrm{HQ}$ and base of operations & \multicolumn{2}{|l|}{$\mathrm{N}$} & 250,000 & & $\mathrm{Y}$ & 2 years & $\mathrm{N}$ & $\mathrm{Y}$ & $\mathrm{Y}$ \\
\hline MI & & $\mathrm{Y}$ & $\mathrm{Y}$ & HQ and $>50 \%$ of FTEs & $\mathrm{N}$ & & 250,000 & 250,000 & $\mathrm{Y}$ & 3 years & $\mathrm{N}$ & & \\
\hline MN & & $\mathrm{Y}$ & $\mathrm{Y}$ & $\begin{array}{l}\mathrm{HQ} \text { and }>50 \% \mathrm{FTEs}, \\
\text { payroll, and contracts }\end{array}$ & $\mathrm{Y}$ & $<\$ 4 \mathrm{~m}$ in $\mathrm{PE}$ & 125,000 & & $\mathrm{Y}$ & 3 years & $\mathrm{N}$ & $\mathrm{Y}$ & $\mathrm{N}$ \\
\hline NE & & $\mathrm{Y}$ & $\mathrm{Y}$ & HQ & $\mathrm{N}$ & & 300,000 & & $\mathrm{Y}$ & 3 years & $\mathrm{N}$ & $\mathrm{Y}$ & $\mathrm{N}$ \\
\hline NJ & & $\mathrm{N}$ & $\mathrm{Y}$ & Business and $>75 \%$ of FTEs & \multicolumn{2}{|l|}{$\mathrm{N}$} & & 500,000 & & & $\mathrm{~N}$ & $\mathrm{Y}$ & $\mathrm{Y}$ \\
\hline $\mathbf{N M}$ & & $\mathrm{N}$ & $\mathrm{Y}$ & Principal business & $\mathrm{N}$ & & & 62,500 & & & $\mathrm{Y}$ & $\mathrm{Y}$ & \\
\hline NY & & $\mathrm{N}$ & $\mathrm{Y}$ & $\begin{array}{l}\text { Physically resides or has } \\
\text { R\&D activities in NY }\end{array}$ & \multicolumn{2}{|l|}{$\mathrm{N}$} & 150,000 & & \multicolumn{2}{|l|}{$\mathrm{N}$} & $\mathrm{N}$ & $\mathrm{Y}$ & $\mathrm{Y}$ \\
\hline NC & & $\mathrm{N}$ & $\mathrm{N}$ & & $\mathrm{N}$ & & & 50,000 & $\mathrm{Y}$ & 1 year & $\mathrm{N}$ & $\mathrm{N}$ & $\mathrm{N}$ \\
\hline ND & & $\mathrm{N}$ & $\mathrm{Y}$ & $\begin{array}{l}\text { Principal business, }>50 \% \text { of } \\
\text { businesses/sales and FTEs }\end{array}$ & \multicolumn{2}{|l|}{$\mathrm{N}$} & 112,500 & & & & $\mathrm{~N}$ & $\mathrm{Y}$ & \\
\hline \multirow{2}{*}{ OH } & a. & $\mathrm{N}$ & $\mathrm{Y}$ & $\begin{array}{l}\text { Principal business, }>50 \% \text { of } \\
\text { gross assets and FTEs }\end{array}$ & $\mathrm{N}$ & & 62,500 & & & & $\mathrm{~N}$ & $\mathrm{~N}$ & \\
\hline & $b$. & $\mathrm{N}$ & $\mathrm{Y}$ & $\begin{array}{l}\text { Principal business, }>50 \% \text { of } \\
\text { gross assets and FTEs }\end{array}$ & $\mathrm{N}$ & & 62,500 & & & & $\mathrm{~N}$ & $\mathrm{~N}$ & \\
\hline OK & & $\mathrm{Y}$ & $\mathrm{Y}$ & Principal business & & & & & & & $\mathrm{N}$ & & \\
\hline RI & & & & & & & & 100,000 & & & & $\mathrm{Y}$ & \\
\hline SC & & $\mathrm{N}$ & $\mathrm{Y}$ & HQ & $\mathrm{N}$ & & 100,000 & & $\mathrm{Y}$ & 2 years & $\mathrm{Y}$ & $\mathrm{Y}$ & $\mathrm{Y}$ \\
\hline TN & & $\mathrm{Y}$ & $\mathrm{Y}$ & $\begin{array}{l}\text { Product derived from R\&D } \\
\text { in TN. }>60 \% \text { of FTEs }\end{array}$ & $\mathrm{N}$ & & 50,000 & & & & $\mathrm{Y}$ & & $\mathrm{Y}$ \\
\hline VA & & $\mathrm{N}$ & $\mathrm{Y}$ & $\begin{array}{l}>50 \% \text { gross receipts and }> \\
80 \% \text { expenses }\end{array}$ & $\mathrm{Y}$ & $\begin{array}{l}<\$ 3 \mathrm{~m} \text { in } \\
\text { equity or debt }\end{array}$ & 50,000 & & $\mathrm{Y}$ & 3 years & $\mathrm{N}$ & $\mathrm{N}$ & \\
\hline Wv & & $\mathrm{N}$ & $\mathrm{Y}$ & HQ & $\mathrm{N}$ & & 50,000 & & $\mathrm{Y}$ & 5 years & $\mathrm{N}$ & & \\
\hline WI & & $\mathrm{N}$ & $\mathrm{Y}$ & $\mathrm{HQ}$, and $>50 \%$ of FTEs & $\mathrm{Y}$ & $<\$ 10 \mathrm{~m}$ in $\mathrm{PE}$ & & & $\mathrm{Y}$ & 3 years & $\mathrm{Y}$ & & \\
\hline
\end{tabular}




\section{Table A.2: Aggregate State-Year Summary Statistics}

\begin{tabular}{|c|c|c|c|c|c|c|}
\hline \multicolumn{7}{|c|}{$\begin{array}{c}\text { Panel } 1 \\
\text { States with Tax Credit Programs }\end{array}$} \\
\hline & Mean & SD & Min & Med & $\operatorname{Max}$ & Obs \\
\hline Angel \& Seed Amount & 58.01 & 154.13 & 0.00 & 14.95 & 1094.73 & 178 \\
\hline Num of Angel Deals & 80.15 & 307.79 & 0.00 & 7.00 & 2739.00 & 259 \\
\hline Num of Angel Investors in Local Companies & 63.66 & 230.46 & 0.00 & 6.00 & 1980.00 & 259 \\
\hline Num of Angel Investors from State & 42.82 & 140.52 & 0.00 & 6.00 & 1055.00 & 259 \\
\hline Employment at Firms 0-5 Yrs Old (in 1000s) & 237.62 & 223.67 & 33.23 & 184.88 & 1119.28 & 254 \\
\hline High Tech \& Manuf. Emp. at Firms 0-5 Yrs Old (in 1000s) & 25.24 & 26.70 & 1.92 & 16.32 & 174.92 & 254 \\
\hline Num of Manufacturing Firms (in 1000s) & 3.73 & 3.41 & 0.50 & 2.57 & 15.98 & 234 \\
\hline Num of High Tech Firms (in 1000s) & 7.66 & 7.36 & 0.47 & 4.72 & 30.35 & 234 \\
\hline Num of Non-Prof Investors (w Exit) & 24.79 & 90.40 & 0.00 & 3.00 & 731.00 & 259 \\
\hline Num of Prof Investors (w Exit) & 38.88 & 142.50 & 0.00 & 3.00 & 1249.00 & 259 \\
\hline Num of Non-Prof Investors & 14.10 & 49.97 & 0.00 & 1.00 & 400.00 & 259 \\
\hline Num of Prof Investors & 35.54 & 131.49 & 0.00 & 3.00 & 1172.00 & 259 \\
\hline
\end{tabular}

Panel 2

States without Tax Credit Programs

\begin{tabular}{lcccccc} 
& Mean & SD & Min & Med & Max & Obs \\
\hline Angel \& Seed Amount & 94.53 & 374.99 & 0.00 & 12.20 & 4322.58 & 266 \\
Num of Angel Deals & 96.11 & 698.54 & 0.00 & 1.00 & 11060.00 & 761 \\
Num of Angel Investors in Local Companies & 64.62 & 392.60 & 0.00 & 1.00 & 5221.00 & 761 \\
Num of Angel Investors from State & 44.56 & 256.35 & 0.00 & 2.00 & 3156.00 & 761 \\
Employment at Firms 0-5 Yrs Old (in 1000s) & 323.64 & 436.78 & 21.28 & 192.42 & 2668.22 & 650 \\
High Tech \& Manuf. Emp. at Firms 0-5 Yrs Old (in 1000s) & 40.45 & 65.80 & 0.81 & 19.62 & 577.04 & 650 \\
Num of Manufacturing Firms (in 1000s) & 4.61 & 5.65 & 0.08 & 2.64 & 34.50 & 684 \\
Num of High Tech Firms (in 1000s) & 8.14 & 10.97 & 0.37 & 4.30 & 70.98 & 684 \\
Num of Non-Prof Investors (w Exit) & 23.62 & 158.51 & 0.00 & 0.00 & 2224.00 & 761 \\
Num of Prof Investors (w Exit) & 41.00 & 239.12 & 0.00 & 0.00 & 3077.00 & 761 \\
Num of Non-Prof Investors & 13.94 & 92.22 & 0.00 & 0.00 & 1275.00 & 761 \\
Num of Prof Investors & 35.94 & 210.55 & 0.00 & 0.00 & 2724.00 & 761 \\
\hline \hline
\end{tabular}

Note: This table contains summary statistics on aggregate start-up activity by state. Employment and firm data are from the Census QWI and CBP. Angel \& Seed Amount is from the financing data (CB Insights, Crunchbase). Number of angel deals and investors are from AngelList. Investors are classified as professional by two definitions: (1) their companies ever has an exit in the data (Num of Prof/Non-Prof Investors (w Exit))and (2) have at least one exit and at least two deals per year (Num of Prof/Non-Prof Investors). 
Table A.3: Robustness Tests of Aggregate Tax Credit Effect

\begin{tabular}{|c|c|c|c|c|c|c|c|c|c|}
\hline \multirow[t]{2}{*}{ Dependent variable: } & \multicolumn{3}{|c|}{$\begin{array}{l}\text { Employment High Tech, } \\
\text { Manuf Firms 0-5 yrs Old }\end{array}$} & \multicolumn{3}{|c|}{$\begin{array}{l}\text { Num Angel } \\
\text { Deals }\end{array}$} & \multicolumn{3}{|c|}{$\begin{array}{l}\text { Num Angel Investors } \\
\text { in Local Companies }\end{array}$} \\
\hline & $(1)$ & $(2)$ & $(3)$ & (4) & $(5)$ & $(6)$ & $(7)$ & (8) & $(9)$ \\
\hline \multirow[t]{2}{*}{ Tax Credit } & 0.005 & 0.007 & 0.022 & $0.348^{* *}$ & $0.286^{*}$ & 0.247 & $0.328^{* *}$ & $0.272^{*}$ & 0.236 \\
\hline & {$[-0.05,0.06]$} & {$[-0.05,0.07]$} & {$[-0.04,0.08]$} & {$[0.06,0.6]$} & {$[-0.03,0.6]$} & {$[-0.06,0.6]$} & {$[0.06,0.6]$} & {$[-0.03,0.6]$} & {$[-0.06,0.5]$} \\
\hline Observations & 725 & 725 & 904 & 735 & 735 & 1020 & 735 & 735 & 1020 \\
\hline$R^{2}$ & 0.646 & 0.732 & 0.746 & 0.591 & 0.685 & 0.644 & 0.588 & 0.680 & 0.641 \\
\hline State FE & $\mathrm{Y}$ & $\mathrm{Y}$ & $\mathrm{Y}$ & $\mathrm{Y}$ & Y & $\mathrm{Y}$ & $\mathrm{Y}$ & $\mathrm{Y}$ & $\mathrm{Y}$ \\
\hline Year FE & $\mathrm{Y}$ & $\mathrm{Y}$ & $\mathrm{Y}$ & $\mathrm{Y}$ & $\mathrm{Y}$ & $\mathrm{Y}$ & $\mathrm{Y}$ & $\mathrm{Y}$ & $\mathrm{Y}$ \\
\hline Division-Year FE & & $\mathrm{Y}$ & & & $\mathrm{Y}$ & & & $\mathrm{Y}$ & \\
\hline Controls & & $\mathrm{Y}$ & $\mathrm{Y}$ & & $\mathrm{Y}$ & $\mathrm{Y}$ & & $\mathrm{Y}$ & $\mathrm{Y}$ \\
\hline Extended Sample & & & $\mathrm{Y}$ & & & $\mathrm{Y}$ & & & $\mathrm{Y}$ \\
\hline
\end{tabular}

Note: This table contains Extended Sample means that the sample includes CA, MA, and all years. Standard errors are in parentheses.

㐘 ${ }^{*} p<0.10,{ }^{* *} p<0.05,{ }^{* * *} p<0.01$ 
Table A.4: Comparison of Pre- and Post-Match Covariates by Tax Credit Status

\begin{tabular}{|c|c|c|c|c|c|c|c|c|}
\hline \multirow[b]{4}{*}{ Year Founded } & \multicolumn{8}{|c|}{$\begin{array}{c}\text { Panel } 1 \\
\text { Pre-Match }\end{array}$} \\
\hline & \multicolumn{3}{|c|}{ Got Tax Credit } & \multicolumn{3}{|c|}{ No Tax Credit } & \multicolumn{2}{|c|}{ T-Test } \\
\hline & Mean & $\mathrm{SD}$ & Obs & Mean & SD & Obs & t-value & $\mathrm{p}$-value \\
\hline & 2009.6 & 4.652 & 619 & 2008.6 & 6.549 & 20403 & -3.797 & 0.000147 \\
\hline Total Financing & 10.17 & 27.77 & 619 & 14.43 & 158.7 & 20403 & 0.668 & 0.504 \\
\hline Average Emp & 6.221 & 9.838 & 619 & 23.07 & 563.2 & 20403 & 0.744 & 0.457 \\
\hline Average Sales & 720732.7 & 3111565.6 & 619 & 4554826.4 & 241016016.1 & 20403 & 0.396 & 0.692 \\
\hline Exit Rate & 0.107 & 0.309 & 619 & 0.153 & 0.360 & 20403 & 3.144 & 0.00167 \\
\hline
\end{tabular}

Panel 2

Post-Match: Different State, Narrow Sectors

\begin{tabular}{|c|c|c|c|c|c|c|c|c|}
\hline \multirow[b]{3}{*}{ Year Founded } & \multicolumn{3}{|c|}{ Got Tax Credit } & \multicolumn{3}{|c|}{ No Tax Credit } & \multicolumn{2}{|c|}{ T-Test } \\
\hline & Mean & $\mathrm{SD}$ & Obs & Mean & SD & Obs & t-value & p-value \\
\hline & 2009.5 & 4.137 & 517 & 2009.3 & 3.803 & 3129 & -1.282 & 0.200 \\
\hline Total Financing & 10.15 & 27.25 & 517 & 8.106 & 23.28 & 3129 & -1.035 & 0.301 \\
\hline Average Emp & 6.450 & 10.55 & 517 & 7.811 & 88.61 & 3129 & 0.386 & 0.700 \\
\hline Average Sales & 777256.0 & 3390226.5 & 517 & 663930.9 & 3015808.0 & 3129 & -0.661 & 0.508 \\
\hline Exit Rate & 0.110 & 0.314 & 517 & 0.127 & 0.333 & 3129 & 1.175 & 0.240 \\
\hline
\end{tabular}

Note: This table compares covariates across treatment and control, both before (panel 1) and after the matching process (panel 2) used as robustness. In each panel, we examine firms' founding year, total financing, sales, and employment, and exit-rate. The pre-match universe of potential controls includes all companies in the financing data that received angel or seed investment. 


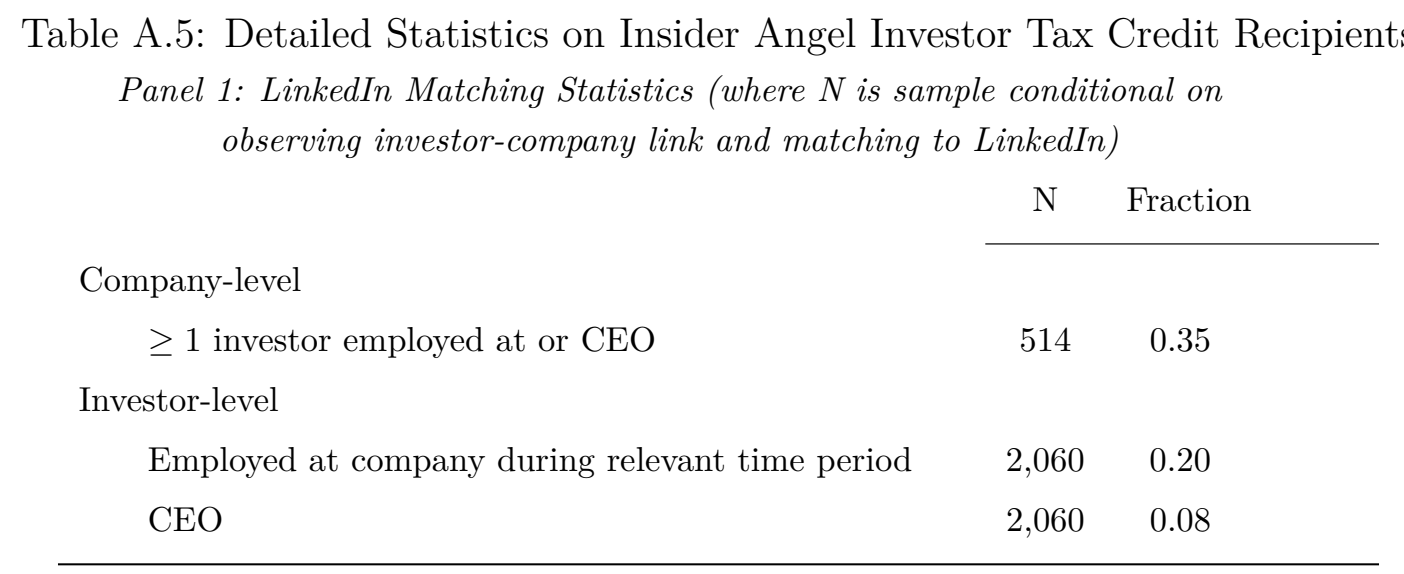

Panel 2: SEC Form D Matching Statistics (where $N$ is sample conditional on observing investor-company link and matching to Form D)

$\mathrm{N} \quad$ Fraction

Company-level

$\geq 1$ investor executive or family of executive

$186 \quad 0.21$

Investor-level

Executive

$1,416 \quad 0.03$

Family of executive officer

$1,416 \quad 0.02$

Panel 3: Multiple Last Name Matching Statistics (where $N$ is sample conditional on observing investor-company link and having $\geq 3$ investors with same last name)

$\mathrm{N} \quad$ Fraction

Company-level

$\begin{array}{llll}\geq 1 \text { investor executive or shares executive last name } & 61 & 0.61\end{array}$

Investor-level

Executive

$285 \quad 0.35$

Shares last name of executive

$285 \quad 0.24$

Note: This table describes information from the five states where we observe beneficiary companies linked to the investors who received tax credits for investing in them. In panel 1, we report whether an investor is an employee of the firm, either as a CEO or not. These variables are constructed using Linkedin information. In panel 2, we report information on whether an investor is an executive or family member of an executive. In particular, we first report the share of firms in which at least one investor is an executive or family of an executive and then the share of investors that are either an executive or family of an executive. Information on the identity of executives are collected from SEC form D. We define an investor as a family member of an executive if she has the same surname of an executive. In panel 3, we report information on whether several investors belong to the same family. In particular, we first identify the share of firms in which there are at least three investors with the same surname. Second, we report the share of investors that has the same surname of at least two other investors in the same firm. 